\title{
POJAM I ZNAČAJ POSLIJEPENALNE ZAŠTITE - KOGA ŠTITITI, ZAŠTO I KAKO?
}

\author{
Snježana Maloić \\ Ministarstvo pravosuđa, Uprava za zatvorski sustav i probaciju, \\ Sektor za probaciju \\ E-mail: snjezana.maloic@pravosudje.hr
}

\begin{abstract}
SAŽETAK
Poslijepenalna zaštita iznimno je složeno i zahtjevno područje rada kojemu se u našoj, ali i u drugim zemljama, pridaje premalo političke, društvene, financijske pa i stručne i znanstvene pozornosti. Ta je tema, ako govorimo o punoljetnim počiniteljima kaznenih djela kojima je izrečena kazna zatvora, vrlo malo zastupljena u recentnoj domaćoj, stručnoj i znanstvenoj literaturi pri čemu se u postojećoj upozorava na manjkavosti u ovom području. Prema informacijama dostupnima autorici, novijih domaćih istraživanja nema.

Ovim se radom nastoji upozoriti na značaj poslijepenalne zaštite u svrhu socijalne reintegracije otpuštenih zatvorenika, u smislu zaštite zatvorenika, njegove obitelji, poznatih i potencijalnih žrtava, njihovih obitelji i društva u cjelini, te pružiti podršku državnim i javnim institucijama i nevladinu sektoru u kreiranju promišljenih i znanstveno utemeljenih mjera poslijepenalne zaštite. Svrha je rada doprinijeti većoj znanstvenoj utemeljenosti i učinkovitosti intervencija koje se u našoj zemlji poduzimaju na području poslijepenalne zaštite. Ciljevi su rada: (1) doprinijeti boljem razumijevanju znanstvenika i stručnjaka na terminološkoj razini, (2) rezultate suvremenih empirijskih istraživanja staviti u kontekst unapređivanja aktualne hrvatske prakse i (3) potaknuti akademski interes za poslijepenalnu zaštitu.

U okviru zaključaka donose se preporuke za uporabu pojmova povezanih s tim područjem i unapređenje poslijepenalne zaštite u našoj zemlji te prijedlozi tema i područja koja bi bilo potrebno dodatno analizirati novim domaćim radovima i znanstvenim istraživanjima.
\end{abstract}

Ključne riječi: postpenalni prihvat, poslijepenalna zaštita, zatvor, zatvorenik, socijalna reintegracija

\section{UVOD}

Tema poslijepenalne zaštite, ako govorimo o punoljetnim počiniteljima kaznenih djela kojima je izrečena kazna zatvora, vrlo je malo zastupljena u recentnoj domaćoj stručnoj i znanstvenoj literaturi. Na terminološkoj razini, susrećemo se s pojmovima postpenalnog/ne, poslijepenalnog/ ne i postinstitucijskog /ne prihvata, tretmana, pomoći, zaštite, odnosno posttretmana i posttretmanske zaštite (Mikšaj, 1982; Previšić i Leko, 1988; Žakman-Ban, 1992; Koller-Trbović i Mirosavljević, 2005; Jandrić, Puljić i Cetinić, 2005; Knežević, 2008:306; Maloić, Ricijaš i Rajić, 2012; Maloić, Rajić i Mažar, 2015; Lončar, 2016; Penić, Malek i Vlahović, 2017; Edukacijsko-rehabilitacijski fakultet, 2019). Nameće se pitanje, radi li se o sličnim pojmovima s istim značenjem ili o različitim pojmovima različita značenja. Uvidom u stranu literaturu također nailazimo na različite pojmove - engl. reentry, resettlement, aftercare, throughcare, uz različita tumačenja tih pojmova (Travis, 2000; Petersilia, 2004; Taxman, 2004; Fox, Khan, Briggs, Rees-Jones, Thompson i Owens, 2005; La Vigne, Solomon, Beckman, Dedel, 2006; Maruna, 2006; Burnett i Maruna, 2006; Maguire, 2011; Serin, Lloyd i Hanby, 
2010; Vijeće Europe, 2010; MacDonald, Williams i Kane, 2013; Décarpes i Durnescu, 2014; McNally i Brennan, 2015).

I u domaćoj i u stranoj literaturi naglašava se značaj rehabilitacijskog rada sa zatvorenicima tijekom izvršavanja zatvorske kazne i njihove postupne, odnosno kasnije socijalne reintegracije u društvo. No, aktivnosti i sadržaji koji se u tom smjeru nude, ocjenjuju se nedostatnima ili se upozorava na nužna poboljšanja u provedbi (Petersilia, 2001; Travis, Solomon i Waul, 2001; Petersila, 2004; Taxman, 2004; Knežević, 2008; Nugent i Pitts, 2009; Cowe, 2012; Lewis, 2013; MacDonald i sur., 2013; Joldersma, 2016; Penić i sur., 2017). Kao mogući razlozi navode se nedovoljna informiranost i osviještenost o učincima (ne)rada na tom području, nedovoljan politički interes pa time i nedostatni resursi, općeniti nedostatak interesa u društvu, manjak povezanosti znanosti i prakse, premalo istraživanja i/ili nedovoljno uzimanja u obzir rezultata istraživanja (Welsh, 2004; McNeill, 2006; Durnescu, 2011; Décarpes i Durnescu, 2014; Tabar i sur., 2016).

Ovaj rad donosi pregled aktualnih inozemnih i domaćih spoznaja uz kritički osvrt. Svrha je rada doprinijeti većoj znanstvenoj utemeljenosti i povećanju učinkovitosti intervencija koje se u našoj zemlji poduzimaju na području poslijepenalne zaštite. Ciljevi su rada: (1) doprinijeti boljem razumijevanju znanstvenika i stručnjaka na terminološkoj razini, (2) rezultate suvremenih empirijskih istraživanja staviti u kontekst unapređivanja aktualne hrvatske prakse u vidu preporuka i (3) potaknuti akademski interes za poslijepenalnu zaštitu uz preporuke tema novih radova i znanstvenih istraživanja.

\section{POJAM POSLIJEPENALNE ZAŠTITE}

Uvidom u stranu literaturu vezanu uz tu tematiku nailazimo na različite pojmove, pri čemu se najčešće susrećemo s pojmovima reentry odnosno re-entry i resettlement. Općenito govoreći, pod tim se pojmovima podrazumijevaju intervencije koje se poduzimaju u svrhu prevencije ponovnoga počinjenja kaznenog djela otpuštenog zatvorenika, pri čemu su neke jurisdikcije i društva u tom smjeru skloniji staviti naglasak na sadržaje kao što su: obveze, nadzor, ograničenja, zabrane i slično, dok su drugi skloniji intervencijama usmjerenima na socijalnu reintegraciju, to jest tretmanskim sadržajima i programima socijalne podrške općenito. O navedenom će se preciznije govoriti u nastavku rada.

U okviru Standardnih minimalnih pravila Ujedinjenih naroda za postupanje sa zatvorenicima - tzv. Mandelinih pravila (United Nations, 2016) i Europskih zatvorskih pravila (Council of Europe, 2006) posebno se naglašava reintegracija zatvorenika u društvo (engl. reintegration into society). Nužnim se naglašava svakom zatvoreniku osigurati mogućnosti za razvoj vještina i osobnih odnosa, na način koji će smanjiti vjerojatnost recidiva nakon otpusta, uz reintegraciju u društvo nakon izvršene zatvorske kazne. Jasno se naglašava nužnost niza elemenata za učinkovito izvršavanje kazne zatvora u smjeru socijalne reintegracije zatvorenika, od kojih su ovdje izdvojeni samo relevantniji u odnosu na temu i sadržaj rada:

— život u zatvoru treba biti, koliko god je to moguće, sličan pozitivnim aspektima života u zajednici 
— medicinska skrb treba biti u skladu sa zdravstvenim uslugama koje se pružaju izvan zatvora i povezana s ustanovama koje ju pružaju

— potrebno je poticati suradnju s vanjskim pružateljima socijalnih usluga i koliko god je moguće uključenost civilnog društva u život u zatvoru

- zatvorenicima je potrebno osigurati pristup obrazovanju i stručnom, odnosno radnom osposobljavanju, radu, tretmanskim programima i smislenim okupacijskim aktivnostima

— nužna je priprema zatvorenika za otpust - potrebno je osigurati identifikacijske dokumente, dokumentaciju (npr. medicinsku) te pomoć u nalaženju prikladna smještaja i posla.

Ured za droge i kriminal Ujedinjenih naroda (United Nations Office on Drugs and Crime, 2012) o re-entry govori u kontekstu kraja zatvorske kazne, bilo da se zatvorenik otpušta uvjetno uz superviziju bilo bezuvjetno nakon punog isteka kazne. Naglasak je na procesu kojim zatvorenici prolaze od zatvaranja pa do života u zajednici. Kao glavni cilj intervencija u tom procesu navodi se pomoć otpuštenim zatvorenicima u prevladavanju stigme i drugih štetnih učinaka zatvaranja, kao i brojnih prepreka s kojima se suočavaju prilikom reintegracije u zajednicu. Ističe se ključni značaj adekvatna odgovora na čimbenike koji utječu na činjenje kaznenih djela i na fizičke i socijalne potrebe zatvorenika tijekom i nakon zatvaranja te prilikom reintegracije. Napominje se da se ovakve intervencije nazivaju i throughcare, aftercare, transitional services, resettlement ili social reintegration. Pojam resettlement programme definira se kao sustavna i na dokazima utemeljena intervencija u okviru rada sa zatvorenicima tijekom kazne i nakon otpusta, u svrhu bolje zaštite zajednice od štete i smanjenja recidivizma.

Pojam resettlement Vijeće Europe (Council of Europe, 2010) Europskim probacijskim pravilima definira proces reintegracije zatvorenika u zajednicu na pozitivan način, koji započinje tijekom zatvaranja. Taj se pojam koristi samo kod zatvorenika koji su nakon izlaska iz zatvora i nadalje dužni ispunjavati određene obveze, to jest odnosi se samo na uvjetovanu uključenost osuđenika, koja bi u slučaju odbijanja rezultirala povratkom u zatvor. Pojmom aftercare podrazumijeva se proces reintegracije otpuštenog zatvorenika u zajednicu uz njegovu dobrovoljnu uključenost u programe pomoći i zaštite nakon otpusta iz zatvora.

Na pojam reentry najčešće nailazimo u američkoj literaturi, dok se u europskoj literaturi u pravilu susrećemo s pojmom resettlement. La Vigne i sur. (2006) komentirajući pojam reentry napominju da se zapravo radi o novom nazivu za nešto što je u Sjedinjenim Američkim Državama (SAD) poznato već više od tri stoljeća, od zatvaranja prvih počinitelja kaznenih djela. Maruna (2006) uočava da se danas, za razliku otprije, termini rehabilitacija i reintegracija zatvorenika u društvo sve manje koriste u SAD-u i u Ujedinjenom Kraljevstvu. Komentira da reentry doslovce znači kretanje osobe iz jedne situacije u drugu, da u kontekstu reakcije društva na počinjenje kaznenog djela ne znači zapravo ništa te da pojam svatko može tumačiti kako želi. Za termin resettlement također konstatira da ima niz mogućih značenja i interpretacija. Takvu situaciju tumači posljedicom utjecaja pokreta Ništa ne funkcionira (engl. Nothing works) u rehabilitaciji zatvorenika 70-ih i 80-ih godina prošlog stoljeća, koji je imao snažniji odjek u tim zemljama. Ipak, termini rehabilitacija i reintegracija i nadalje su prisutni na američkom, a posebno na europskom području (Wormith, Althouse, Simpson, Reitzel, Fagan i Morgan, 2007; McNeill, 2012). Primjerice, temeljna su načela 
njemačkoga, nizozemskoga i danskoga sustava resocijalizacija i rehabilitacija, pri čemu se posebno u Njemačkoj specifičan značaj daje i reintegraciji zatvorenika (Rentzmann, 2008; Subramanian i Shames, 2013). Kada govori o reentry procesu, Taxman (2004) pojašnjava da je nužno odgovoriti na potrebe preživljavanja (hrana, smještaj, zaposlenje) otpuštenog zatvorenika, ali i na potrebu razvoja vještina (tretman, pismenost, radno osposobljavanje i slično), dakle taj proces sagledava s gledišta rehabilitacijskog pristupa. Isti autor (Taxman, 2004) kao ciljeve reentry procesa naglašava i poboljšanje sigurnosti u društvu osiguravanjem usluga otpuštenim zatvorenicima, za koje je dokazano da smanjuju rizik recidivizma i da doprinose reintegraciji u zajednicu.

Décarpes i Durnescu (2014) se u svojem radu odlučuju za pojam resettlement. Taj termin vide moralno neutralnijim od prema njima "starim" pojmovima, kao što su aftercare ili throughcare, smatrajući da je kod tih pojmova naglasak previše na brizi. Pojašnjavaju da pojam resettlement podrazumijeva sve programe i intervencije kojima je cilj prevladavanje prepreka ili pomaganje otpuštenim zatvorenicima u procesu reintegracije. Osim hrane, smještaja i izvora financiranja izravno nakon izlaska iz zatvora, ističu značaj rada i na drugim segmentima tijekom kazne zatvora i nakon otpusta, kao što su: razmišljanje i ponašanje, radno osposobljavanje i zapošljavanje, mentalno i fizičko zdravlje, zlouporaba alkohola i droga, financije, olakšice i dugovi. Skreću pozornost da se u tom smislu u Njemačkoj koristi pojam Übergangsmanagement. Navode da je taj pojam istoznačan pojmu reentry, kako ga definira Petersilia (2004), dakle da se odnosi na sve aktivnosti kojima zatvorenik provodi svoje vrijeme tijekom zatvaranja, u okviru procesa otpusta i supervizije nakon otpusta.

Unatoč mišljenju Décarpesa i Durnescuoa (2014) o zastarjelosti pojmova throughcare i aftercare, u relativno recentnoj literaturi i nadalje se koriste ti pojmovi (Fox i sur., 2005; Vijeće Europe, 2010; MacDonald i sur., 2013). Fox i sur. (2005) pojam throughcare definiraju kao model za upravljanje kontinuitetom brige, koja počinje prvim kontaktom počinitelja kaznenog djela s kaznenopravnim sustavom, pritvaranjem, suđenjem, izvršavanjem kazne i sve do resettlement, dakle throughcare vide širim pojmom od resettlement i aftercare. Isti autori (Fox i sur., 2005) aftercare definiraju kao paket podrške koji treba biti spreman kada zatvorenik dostigne završetak svojeg tretmanskog programa u zatvoru i vraća se u zajednicu.

U slovenskoj literaturi susrećemo se s pojmovima pokazenska pomoč, postpenalna obravnava $i$ postpenalna pomoč, koji se donekle koriste kao sinonimi (Brinc, 1976; Brinc, 1982; Brinc, 1989; Kobal i Žakelj, 2007; Vidmar, 2016). Primjerice, Vidmar (2016) navodi da se radi o pomoći koja se pruža otpuštenim zatvorenicima nakon prestanka zatvorske kazne i otpusta na slobodu, u svrhu što lakšeg i učinkovitijeg uključivanja u društveni život. Na isti način Marussig (2017) definira pojam postpenalne obravnave, dodajući da se tim pojmom obuhvaća pomoć pri pronalasku smještaja, traženju zaposlenja te vezano uz obiteljske odnose, kao i psihološka potpora. Mahmutović i Hasanbegović (2007) u svojem radu, vezano uz potrebe i poteškoće zatvorenica na području Federacije BiH, koriste se pojmom postpenalna pomoć, koju potom dijele na unutarnju, u vidu neposredne pripreme za otpust iz ustanove i vanjsku koja se pruža izravno nakon otpusta iz penalne ustanove. Vanjsku postpenalnu pomoć definiraju kao davanje moralne potpore i pomoći otpuštenoj zatvorenici u svrhu učinkovita nošenja sa svakodnevnim izazovima, dobra ponašanja te izbjegavanja okolnosti koje bi mogle dovesti do kriminalnog povrata (Petrović i Jovašević, 2006, prema Mahmutović i Hasanbegović, 2007). Stevanović, Petrović, Međedović i Vujičić (2018) također se koriste pojmom postpenalna pomoć, pri čemu navode da se radi o moralnoj i materijalnoj podršci zatvoreniku, 
kojom se započinje još tijekom zatvorske kazne. Ističu da je Zakonom o izvršenju krivičnih sankcija (Službeni glasnik RS, br. 55/2014) u Srbiji propisano da će se postupak pružanja pomoći i prihvata zatvorenika urediti posebnim zakonom (što ostaje i nakon izmjena Zakona, Službeni glasnik RS, br. 35/2019), no da Zakon o postpenalnoj pomoći nije donesen. Navode da se postpenalna pomoć u praksi pruža isključivo u situacijama odsutnosti smještaja zatvorenika nakon otpusta (kada zatvor obavještava centar za socijalnu skrb radi pronalaska smještaja), a da vezano uz zapošljavanja i druge segmente života postpenalni prihvat zapravo ne funkcionira. Ured za droge i kriminal Ujedinjenih naroda (2012) navodi da zapravo nisu rijetke situacije da zakoni i politike pretpostavljaju postojanje reintegracijskih programa u zatvorima i u zajednici, dok su u stvarnosti takvi programi dostupni samo malom postotku zatvorenika. Srnić i Vulević (2016) govore o pojmu postpenalne pomoći i podrške koji prema ovim autorima podrazumijeva mjere i postupke koji se poduzimaju radi uključivanja otpuštenih zatvorenika u život na slobodi, pri čemu postpenalnu pomoć kao Mahmutović i Hasanbegović (2007) dijele na unutarnju, s kojom se započinje u zatvoru tijekom izvršavanja kazne zatvora i vanjsku, s kojom se započinje nakon izlaska na slobodu.

Analizirajući domaće zakonodavstvo, možemo vidjeti da je prije vrijedeći Zakon o izvršenju sankcija izrečenih za kaznena djela, privredne prijestupe i prekršaje (NN 21/74, 153/09) u okviru glave VII propisivao otpuštanje osuđenih osoba i postpenalnu pomoć. Aktualni Zakon o izvršavanju kazne zatvora (NN 128/99, 98/19) taj pojam više ne spominje. Propisanom svrhom i drugim odredbama normativno slijedi ranije spomenuta Standardna minimalna pravila Ujedinjenih naroda kao i Europska zatvorska pravila. Susrećemo se s pojmovima pripreme za otpust i pomoći poslije otpusta, koji se sadržajno definiraju putem nekoliko članaka. Propisana je obveza kaznionice, odnosno zatvora da pravodobno organizira pripremu zatvorenika za otpuštanje u suradnji s ustanovama i drugim pravnim osobama u čijem su djelokrugu poslovi pomoći poslije otpusta. Navodi se da se s pripremom zatvorenika za otpust treba započeti odmah nakon dolaska u kaznionicu ili zatvor, uz obvezu kaznionice i zatvora da najkasnije tri mjeseca prije otpusta uključe zatvorenika u pojedinačni ili skupni savjetodavni rad u svezi s pripremanjem zatvorenika za otpust. Nakon otpusta iz kaznionice odnosno zatvora, otpušteni zatvorenik može se obratiti nadležnom sucu izvršenja radi pružanja pomoći i podrške, pri čemu sudac izvršenja surađuje s centrom za socijalnu skrb. Također, propisano je da će na zahtjev kaznionice, odnosno zatvora, ured za probaciju obaviti poslove pripreme prihvata zatvorenika poslije otpusta u skladu sa zakonom koji propisuje poslove probacije.

Prvim Zakonom o probaciji (NN 153/09) iz 2009. godine kao probacijski posao bila je propisana i priprema prihvata poslije otpusta. Međutim, snažna gospodarska kriza u zemlji i svijetu usporavala je razvoj službe, a time je bio odgođen i početak izvršavanja ovog posla, koji od 2013. godine Zakonom o probaciji (NN 143/12) više nije bio propisan probacijskim poslom, a nije ni vrijedećim Zakonom o probaciji (NN 99/18). Probacijska služba sada je tijekom izvršavanja kazne zatvora uključena kod dostave izvješća u postupku odlučivanja o prekidu izvršavanja kazne zatvora i uvjetnom otpustu te pri izvršavanju uvjetnog otpusta. Izazove koje, vezano uz praksu poslijepenalne zaštite, navode Stavenović i sur. (2018), možemo prepoznati i u domaćoj praksi, uz navođenje i drugih izazova: prenatrpanost smještajnih kapaciteta u zatvorenim uvjetima, veći postotak zatvorenika koji rade samo na režijskim poslovima održavanja i funkcioniranja zatvora, odnosno kaznionice, poteškoće u održavanju kontakata zatvorenika i članova obitelji, ograničen angažman probacijske službe i ograničenja u sustavu socijalne skrbi (Brozić, Perić i Tepšić, 2017; 
Franjić-Nađ, Badurina-Sertić, Šimić, i Pavešić-Herkov, 2015; Ilijaš i Podobnik, 2018; Jug, 2013; Maloić, Rajić i Mažar, 2015; Ministarstvo pravosuđa, 2020).

Kao što je uvodno navedeno, uobičajeno se u našoj zemlji, u stručnoj i znanstvenoj literaturi, koriste pojmovi postpenalnog/ne, poslijepenalnog/ne i postinstitucijskog ne prihvata, tretmana, pomoći, zaštite, odnosno posttretmana i posttretmanske zaštite. Žakman-Ban (1992) se, govoreći o postpenalnom nadzoru i prihvatu, referira na nadzor otpuštenih zatvorenika, diferencirane penološke programe i razne oblike postpenalne pomoći. Koller-Trbović i Mirosavljević (2005) koriste se pojmom posttretmana, pri čemu sadržaje dijele na materijalne i nematerijalne vrste pomoći, brige i zaštite, dakle ne govore samo o nastavku tretmanskih programa, kako bi se to očekivalo. Penić i sur. (2017) govore o postpenalnom prihvatu zatvorenika, pri čemu navode da postpenalni prihvat obuhvaća postupke prema osobama otpuštenima iz zatvora, odnosno kaznionica u svrhu njihove kvalitetne socijalne reintegracije, kao što je to navela i Mikšaj (1982). Previšić i Leko (1988) koriste se pojmom postinstitucijske zaštite. Navode da se radi o složenom procesu koji treba započeti još u penalnoj ustanovi, od početka izvršavanja kazne zatvora, a obuhvaća pripremu za otpust, otpust i prihvat te vanjsku pomoć i tretman. Knežević (2008) navodi da se kod nas koriste pojmovi postpenalna zaštita i postpenalna pomoć, koji prema tom autoru uključuju najšire oblike institucijskog i neinstitucijskog djelovanja, potom pojam postpenalnog prihvata za koji smatra da uključuje uže djelovanje (obično smještaj i materijalnu pomoć) te pojam postpenalni tretman koji tumači u smislu nastavka terapijskih postupaka, primjerice kod liječenja zbog alkoholizma, zlouporabe droga i sličnog. Temeljem analizirane literature, očito je da se spomenuti pojmovi u stručnoj komunikaciji ponekad koriste kao sinonimi, a ponekad se pod istim pojmom podrazumijevaju različita značenja. U određenoj se mjeri čini nejasnim kojim bi se pojmom trebalo koristiti za što i što točno koji pojam znači. Knežević (2008) zaključuje da ovo pitanje zapravo kod nas nije riješeno na pojmovnom području. Međutim, evidentno je da domaći autori, neovisno o tome kojim se pojmom koriste, govore o radu sa zatvorenicima i otpuštenim zatvorenicima sa stajališta rehabilitacijskog pristupa.

Analizom literature može se zamijetiti da strani, kao i domaći autori u svojim radovima definiraju na što se odnosi pojam koji koriste primarno opisom intervencija koje smatraju potrebnima i/ili onih za koje smatraju da u praksi izostaju. Imajući u vidu sve spomenute pojmove, autorica je u ovom radu odlučila koristiti se pojmom poslijepenalna zaštita, a u sljedećem će se poglavlju nakon prikaza mogućih modela i faza taj izbor i dodatno pojasniti.

\section{MODELI I FAZE POSLIJEPENALNE ZAŠTITE}

Napori usmjereni na smanjivanje recidivizma logično u fokusu imaju počinitelja, neovisno o načinima kako se to nastoji postići - samoizolacijom i onemogućivanjem činjenja kaznenih djela, ili i rehabilitacijom (Damjanović, Šarić i Mikšaj-Todorović, 2000; Kanduč, 1996; 2000; Maloić, 2013). Dostupnom literaturom možemo uočiti više modela reakcije društva na počinjenje kaznenog djela, ovisno o tome koga se primarno nastoji zaštititi. Reakcija može biti primarno usmjerena na: (1) zaštitu i pomoć zatvoreniku, (2) zaštitu zajednice od otpuštenog zatvorenika i (3) zaštitu otpuštenog zatvorenika i zajednice (Maguire, 2011; Maloić, 2013; Petersilia, 2004). Griffiths, Dandurand i Murdoch (2007) analiziraju četiri različito utemeljena modela rada s otpuštenim zatvorenikom, a koji se temelje na: 
(1) riziku - počinitelje kaznenih djela smatra se opasnima te ih je stoga potrebno nadzirati i kontrolirati

(2) potrebama - težište je na kriminogenim potrebama i otpuštenom zatvoreniku nastoji se osigurati adekvatan tretman i usluge

(3) riziku i potrebama - kombinacija dvaju prethodnih modela

(4) snagama - otpuštenog zatvorenika se percipira kao potencijalni resurs (za njegov život i za zajednicu).

Isti autori razlikuju dvije vrste programa koji se provode u zajednici, od kojih prve primarno vide usmjerenima na nadzor, praćenje i kontrolu, a druge na pomoć i podršku otpuštenom zatvoreniku.

Vezano uz reintegraciju zatvorenika u zajednicu, Maguire (2011) pojašnjava da je tradicionalni model, koji je bio u primjeni tijekom 20. stoljeća, uključivao:

1. dobrovoljnu participaciju otpuštenog zatvorenika

2. odgovaranje na potrebe koje bi on sam artikulirao

3. pomoć i podršku u rješavanju praktičnih problema, posredovanjem u pristupanju glavnim pružateljima usluga

4. relativno mali naglasak na ranije kriminalno ponašanje.

Isti autor (Maguire, 2011) uočava zaokret prema novom modelu u posljednje vrijeme, čijim obilježjima navodi:

1. jak fokus na kriminalno ponašanje i njegovu redukciju

2. sustavna procjena potreba i rizika koji predstavlja otpušteni zatvorenik

3. naglasak na onim potrebama koje se procjenjuju kriminogenima ili povećavaju rizik

4. određeni stupanj prisile na suradnju u rehabilitacijskim aktivnostima

5. rad na stavovima, vještinama razmišljanja i/ili motivaciji

6. nametanje strogih ograničenja i zahtjeva kao uvjeta otpusta.

Zaključno, Maguire (2011) zaključuje da se pristupi u okviru poslijepenalne zaštite stoga danas razlikuju po tome:

1. u kojoj su mjeri usmjereni na pomaganje počinitelju u dijelu u kojem on to sam smatra potrebnim, a koliko su intervencije koje se poduzimaju izravno povezane s kriminalnim ponašanjem i procijenjenim rizikom ponovnoga počinjenja kaznenog djela

2. koliko se naglasak stavlja na praktičnu pomoć otpuštenim zatvorenicima, a u kojoj mjeri ih se potiče da sami jačaju, razvijaju i jačaju vještine i motivaciju za samostalno rješavanje problema 
3. u kojoj mjeri je uključena prisila, a koliko se ohrabruje dobrovoljna participacija otpuštenog zatvorenika

4. koliko je naglasak na kratkoročnom rješavanju problemskih situacija, a u kojoj mjeri na dugoročnoj održivosti

5. koliko načelno počivaju na volonterskim ili privatnim agencijama, a koliko na državnim

6. započinje li se s radom u zatvoru ili tek nakon otpusta.

Modele poslijepenalne zaštite možemo razlikovati i prema ulozi koju može imati (otpušteni) zatvorenik, to jest u kojoj mjeri može biti aktivni sudionik, ili je zapravo samo aktivni primatelj (Taxman, 2004; Travis i sur., 2001):

1.) prvi se model oslanja na dobrovoljnost zatvorenika, to jest isključivo o njemu ovisi hoće li ili neće tražiti određene usluge i programe, u skladu s tim koliko sam prepoznaje svoje potrebe

2.) u drugom modelu zatvorenik ima ulogu aktivnog primatelja, to jest od njega se u svrhu zaštite zajednice traži pridržavanje naloženih mu obveza i/ili sudskih zabrana ili državne službe, ovisno o procjeni kriminogenih rizika i potreba, uz prijetnju kaznom u slučaju odbijanja

3.) treći model podrazumijeva aktivnu participaciju zatvorenika kojeg se smatra odgovornim za vlastiti proces reintegracije i donošenje odluka pa ga se stoga i aktivno uključuje u analize rizika, potreba i čimbenika koji imaju utjecaj na njegovu uključenost u kriminal, kao i u osmišljavanje načina odgovora na njegove kriminogene potrebe.

S gledišta rehabilitacijskog pristupa, učinkovita se socijalna reintegracija počinitelja vidi ključnim načinom prevencije kriminalnog povrata, to jest zaštite ranijih i novih žrtava, kao i društva u cjelini (Décarpes i Durnescu, 2014; MacDonald i sur. 2013; Maloić, 2013; Mejovšek, 2001; Petersilia, 2004; Raynor i Robinson, 2009; Žakman-Ban, 1992; Welsh, 2004). Uobičajeno se programi socijalne reintegracije dijele na (Mahmutović i Hasanbegović, 2007; United Nations Office on Drugs and Crime, 2012; Srnić i Vulević, 2016): (1) programe koji se nude u instituciji, to jest u zatvoru i (2) programe koji se provode nakon izlaska na slobodu u zajednici. Programe potrebne zatvorenicima u svrhu reintegracije u društvo James (2015) je podijelio u tri faze:

(1) programi koji se provode tijekom zatvorske kazne, čiji je cilj priprema zatvorenika za otpuštanje

(2) programi koji se provode izravno nakon otpuštanja, a svrha im je povezivanje zatvorenika sa zajednicom u ranoj fazi reintegracije, to jest osiguravanje potrebnih usluga

(3) programi usmjereni na dugoročno adekvatno socijalno funkcioniranje otpuštenog zatvorenika u budućnosti (na primjer, zapošljavanje).

Uobičajeno se smatra da priprema zatvorenika za socijalnu reintegraciju treba započeti gotovo s prvim danom izvršavanja zatvorske kazne (Décarpes i Durnescu, 2014), no Travis (2000) upozorava da bi taj proces trebao započeti već tijekom sudskog postupka, pri čemu bi sudac u obrazloženju 
presude osuđeniku trebao reći koji je cilj njegove kazne, tko će sve biti uključen, što se od njega očekuje i koje su njegove mogućnosti. Postavlja pitanje otpuštanja zatvorenika iz zatvora bez ikakve supervizije, naročito tijekom uvjetnog otpusta. Isti je autor (Travis, 2000) mišljenja da svoj status slobodnog građanina otpušteni zatvorenik tek treba "zaslužiti” te da osim odrađene zatvorske kazne i u zajednici treba pokazati svoju sposobnost ponašanja prema društvenim pravilima, pri čemu mu je potrebno osigurati nadzor, podršku i pomoć.

Petersilia (2004) konstatira da je za reentry proces iznimno važno sve što se događa tijekom kazne zatvora u svrhu pripreme zatvorenika za siguran povratak u zajednicu. Posebno važnim u tom procesu navodi: (1) kako zatvorenici provode vrijeme u zatvoru, (2) kako je koncipiran proces otpuštanja i (3) na koji način se s njima radi i kako im se pomaže nakon povratka u zajednicu. Autorica problematizira sagledavanje reentry procesa samo s gledišta nadzora i praćenja zatvorenika. Poziva se na rezultate istraživanja koji govore o neučinkovitosti zatvorskih kazni ako se njihovo izvršavanje svodi samo na izolaciju i onemogućivanje činjenja kaznenih djela, a aktivnosti vezane uz otpust zatvorenika samo na nadzor i praćenje. Naglašava da su takvi pokušaji zaštite društva Sjedinjene Američke Države doveli do najveće stope zatvaranja u svijetu i do najveće stope recidivizma.

Neovisno o poteškoćama njegova provođenja, penološki se tretman ocjenjuje ključnim tijekom kazne zatvora, naročito za promjenu stavova, s obzirom da su bitni za ponašanje i na njih se može u velikoj mjeri utjecati (Mejovšek, 2002). Hermans (2009) navodi da su napori u smjeru socijalne reintegracije zatvorenika uobičajeno dvostruko usmjereni, pri čemu razlikuje:

(1) intervencije usmjerene na promjenu psihološkog funkcioniranja pojedinca

— ističe kognitivno-bihevioralne intervencije, temeljem rezultata istraživanja koji dokazuju da počiniteljima kaznenih djela nedostaju kognitivne vještine potrebne da bi ostvarili svoje osobne želje na način prihvatljiv za druge ljude

(2) intervencije usmjerene na reintegraciju počinitelja u zajednicu

— naglasak je na rješavanju praktičnih problema u okviru rada na socijalnim odnosima, a čije je rješavanje prijeko potrebno za reintegraciju zatvorenika u društvo.

Nakon proučavanja inozemne i domaće literature, a temeljem nepostojanja jasna razgraničenja pojmova koji se u ovom području koriste u hrvatskom kontekstu, čini se primjerenim korištenje pojma poslijepenalna zaštita, pri čemu se taj pojam može koristiti kao krovni pojam za sve ostale ranije spomenute pojmove. Naime, pojmovi tretman, prihvat i pomoć ponajprije asociraju na počinitelja, dok se pojam zaštite, prema mišljenju autorice, može i treba tumačiti šire - u smislu zaštite otpuštenog zatvorenika, ali i zaštite njegove obitelji, postojećih, odnosno potencijalnih žrtava, njihovih obitelji i društva u cjelini. U kontekstu ovog rada odabrani pojam obuhvaća: (1) sve mjere, intervencije i usluge usmjerene na ponovno konstruktivno uključivanje zatvorenika u zajednicu na načine prihvatljive i za otpuštenog zatvorenika i za zajednicu, (2) sve do sada u radu spomenute faze - izricanje presude, izvršavanje kazne zatvora, uvjetni otpust i vrijeme nakon otpusta nakon punog isteka kazne zatvora i (3) provedbu svih modela, intervencija i usluga čija je učinkovitost dokazana, a o čemu se više govori u jednom od sljedećih poglavlja ovog rada. Prijeko je potrebno najprije analizirati razloge za poslijepenalnom zaštitom, s obzirom na nedovoljnu osviještenost o potrebi poslijepenalne zaštite na koju se u literaturi upozorava. 


\section{POTREBA ZA POSLIJEPENALNOM ZAŠTITOM}

Povratak je zatvorenika u zajednicu neizbježna posljedica zatvaranja, to jest otpust iz zatvora nije opcija nego činjenica jer će svi, koji ne umru tijekom kazne zatvora, jednom biti otpušteni iz zatvora (Travis i sur., 2001; Travis i Visher, 2005, prema Petersilia, 2004). Proučavajući dosadašnje napore u socijalnoj reintegraciji zatvorenika, Nugent i Pitts (2009) ističu da su primjerice nezaposlenost, beskućništvo, mentalno zdravlje, alkohol i izolacija bili teme reformi u 19. stoljeću, pri čemu su i nadalje u fokusu sadašnjih inicijativa u 21. stoljeću. Smatraju da svakako postoji napredak u nekim zemljama i u nekim razdobljima i da je taj napredak izvanredan, no ipak zaključuju da je tek nekoliko primjera trajnijih investiranja, s malo stabilnijih i dugotrajnijih primjena učinkovite prakse. I drugi autori potvrđuju da se potrebi poslijepenalne zaštite pridaje premalo političke, društvene, financijske pa i stručne i znanstvene pozornosti te da potreba za poslijepenalnom zaštitom i njezinim učincima nije dovoljno osviještena (Décarpes i Durnescu, 2014; Griffits i Murdoch, 2009; Serin i sur., 2010).

Potrebu za poslijepenalnom zaštitom autori analiziraju s različitih stajališta (Basile, 2002; Butorac, Gracin i Stanić, 2017; Capul, 1973; Décarpes i Durnescu, 2014; Goffman, 1961, prema Joldersma, 2016; Joldersma, 2016; Maloić, 2013; McNally i Brennan, 2015; Mejovšek, 2002; Serin i sur., 2010; Špadijer-Džinić, 1973; Taxman, 2004; Travis i sur., 2001):

(1) mogućih negativnih učinaka zatvaranja na zatvorenika i njegovu obitelj

(2) karakterističnih obilježja zatvorske populacije

(3) izazova povratka u zajednicu nakon otpusta iz zatvora

(4) učinka neuspjele reintegracije na pojedince i društvo u cjelini.

Zbog ograničena obima ovog rada, u nastavku se navode samo osnovne naznake svakog stajališta.

\section{Mogući negativni učinci zatvaranja na zatvorenika i njegovu obitelj}

Izricanje i izvršavanje zatvorskih kazni trebalo bi pridonijeti padu stope kriminaliteta i sigurnosti društva. Međutim, potrebno je imati u vidu da zatvor predstavlja okruženje koje kod zatvorenika može dovesti do pozitivnih učinaka, ali i do negativnih posljedica (Capul, 1973; Goffman, 1961, prema Joldersma, 2016; Griffiths i sur., 2007; Maloić, 2013; Mejovšek, 2001; Mejovšek, 2002; Mejovšek, Lebedina-Manzoni, Lotar i Šarić, 2007; Mikšaj-Todorović i Leko, 1995; Špadijer-Džinić, 1973; Taxman, 2004):

— osoba (naročito kod duljih zatvorskih kazni) gubi zaposlenje, može izgubiti stambeni prostor, osobnu imovinu, posljedica zatvaranja može biti i rastava braka i općenito slabljenje ili gubitak socijalnih veza

— lišenje slobode osoba može doživjeti kao emotivni šok, mogu se pojaviti poteškoće vezane uz mentalno zdravlje, uz stjecanje samouništavajućih navika i stavova 
— zatvorsko okruženje u velikoj mjeri osobu stavlja u poziciju ovisnosti o zatvoru jer, individualne su potrebe podređene potrebama funkcioniranja zatvora - automatizam koji se stvara pod utjecajem strogoga reguliranja života može dovesti do intelektualnog slabljenja, gubitka osobne inicijative i moći prilagođavanja

— postoji mogućnost negativne socijalizacije odnosno prizonizacije, to jest socijalizacije na zatvorske uvjete, koja je najprisutnija kod recidivista čiji su intervali boravka na slobodi relativno kratki i u zatvoru se dobro snalaze

- zatvaranje može izazvati otpor osobe prema društvu koje ju je odbacilo, može dovesti do internalizacije antisocijalnih normi i vrijednosti, uz učenje novih modaliteta činjenja kaznenih djela i uključivanje u kriminalne mreže.

Što je osoba duže vremena zatvorena, jača je povezanost s kriminalnim elementima i identifikacija s kriminalnim vrijednostima, veće su štete u obiteljima i socijalnim odnosima i veće su poteškoće prilikom povratka u zajednicu (United Nations Office on Drugs and Crme, 2012). Istraživanjem koje su proveli Zamble i Porporino (1988; prema Mejovšek, 2002) glavnim su stresorima kod zatvorenika prepoznati: nedostatak obitelji, prijatelja, slobode, posebnih stvari i aktivnosti, sukobi s drugim zatvorenicima, žaljenje ili uznemiravajuće misli u vezi s prošlošću, zabrinutost za budućnost nakon otpusta, dosada, neadekvatnost smještaja, nezadovoljavajuća razina medicinske usluge, nedostatak podrške i pomoći zaduženog osoblja, zabrinutost za osobnu sigurnost i nedostatak željenih programa ili opreme. Kod žena se najštetnijim učinkom zatvaranja opisuje odvojenost od djece i briga za njihovu dobrobit, pri čemu problem može biti dodatno pogoršan izostankom kontakata (O'Neill, 2017).

Važno je znati da učinci zatvaranja ne pogađaju samo zatvorenika, već i djecu i članove obitelji zatvorenih osoba (Brkić, 2013; Maloić, 2013). Obitelji počinitelja često su zaboravljene, iako je zatvaranje člana zapravo obiteljsko iskustvo (Nugent i Pitts, 2009). U nekim situacijama udaljavanje člana koji je financijski ugrožavao obitelji, trošeći financijska sredstva na održavanje svoje ovisnosti, može imati pozitivne učinke na obitelj zatvorenika. Također, članovi obitelji mogu istovremeno biti i žrtve kaznenog djela (Maloić i Rajić, 2012). Međutim, u mnogim slučajevima zatvaranje je traumatičan događaj za obitelji (Travis i sur., 2001). Može dovesti do financijske ugroženosti obitelji, gubitka emocionalne podrške, ali i do socijalne stigme jer je član obitelji u zatvoru, pri čemu navedeno može imati dugoročne posljedice za djecu - gubitak roditelja ili smanjene kontakte s roditeljem, preseljenje, promjenu škole, nenadzirano slobodno vrijeme, razvoj poremećaja u ponašanju i tako dalje (Maloić i Rajić, 2012; Maloić, 2013; Majdak, 2018). Petrović i Jovanović (2019) djecu, čiji su roditelji na izvršavanju kazne zatvora, smatraju kolateralnim žrtvama kriminala, upravo zbog njihove izloženosti riziku izolacije, neprijateljstva i odbacivanja bilo susjeda, nastavnika, vršnjaka, poslodavaca ili članova obitelji. Više je o mogućim kolateralnim posljedicama zatvaranja roditelja na djecu i potrebnim intervencijama i podršci moguće pročitati u domaćoj literaturi budući da je ta tema nešto zastupljenija u našoj zemlji u posljednje vrijeme (Gabelica Šupljika, 2009; Jelavić, 2009; Majdak, 2018; Matak, 2010; Sučić, Knežević i Matijaš 2016; Profaca i Buljan Flander, 2009). 


\section{Obilježja zatvorske populacije}

Zatvorenici općenito predstavljaju rizičniju skupinu u odnosu na ostale počinitelje kaznenih djela, značajno sudjeluju u ukupnom kriminalitetu, u zatvorima su počinitelji najtežih kaznenih djela i najopasniji počinitelji kaznenih djela (Butorac i sur., 2017; Joldersma, 2016).

Počinitelji kaznenih djela i prije zatvaranja nerijetko samo parcijalno i marginalno sudjeluju u ekonomskom, socijalnom, političkom i kulturnom životu zajednice (Maloić i Rajić, 2012). Mogu imati iskustvo ranije socijalne isključenosti i marginalizacije, neki od njih su bili žrtve fizičkog ili emocionalnog nasilja, drugačijeg su kognitivnog funkcioniranja, teže upravljaju emocijama, dominantnije imaju slabije razvijene interpersonalne i socijalne vještine, pojedini su u kriminal uključeni od rane dobi (Doležal i Mikšaj-Todorović, 2008; Griffiths i sur., 2007). Nemaju razvijen osjećaj odgovornosti, vanjskog su lokusa kontrole, subjektivnih procjena, impulzivni (Lotar Rihtarić, Vrselja i BadurinaSertić, 2017; Zomble i Porporino, prema Mejovšek, 2002). Istraživanje koje su proveli Dhami, Mandel, Loewenstain i Ayton (2006) na dijelu zatvorske populacije u SAD-u i u Ujedinjenom Kraljevstvu, upozorilo je na nerealističnu procjenu zatvorenika vezanu uz mogućnost osobnog kriminalnog povrata, odnosno njihov prevelik optimizam u odnosu na službene statistike o recidivizmu. Nadalje, zatvorenici iz UK-a sebi su davali daleko veće šanse da se neće vratiti u zatvor, u odnosu na druge s kojima su izvršavali kaznu zatvora. U okviru analize rezultata istraživanja, naglašava se rizik da zatvorenici koji su vrlo optimistični i rizik recidiva minimaliziraju, mogu propustiti potrebne aktivnosti kojima bi smanjili taj rizik, čak i kada su motivirani da više ne počine kazneno djelo.

Kod zatvorenika su u odnosu na opću populaciju češće prisutne (Jukić i Sabljo, 2017; Joldersma, 2016; Serin, Lloxd i Habby, 2010; Travis i sur., 2001):

(1) poteškoće povezane s mentalnim zdravljem ili drugim zdravstvenim problemima

(2) niža razina obrazovanja i vještina povezanih sa zapošljavanjem

(3) nezaposlenost i prije dolaska na izvršavanje kazne zatvora

(4) zlouporaba droga i alkohola

(5) obiteljska disfunkcionalnost ili odvojenost

(6) neadekvatno stanovanje.

U zatvorskoj se populaciji susrećemo i s određenim postotkom višestrukih povratnika na izvršavanju kazne zatvora (Šućur, 2001):

— povratnici predstavljaju "tvrdo jezgro" u kriminalnoj populaciji

— velika se društvena materijalna sredstva troše na ovu skupinu

— neki povratnici provedu većinu života u zatvoru

— povratnici nepovoljno utječu na ostatak zatvorske populacije

— ova skupina predstavlja permanentnu opasnost za društvo. 
U pojedinim zemljama na recidiviste odlazi čak više od polovice cjelokupnog kriminaliteta (Singer, Kovčo Vukadin i Cajner Mraović, 2002; prema Lotar Rihtarić i sur., 2017). Analizirajući dinamiku i strukturu kriminaliteta u našoj zemlji u razdoblju od 1997. do 2011. godine, Kovčo Vukadin (2011) skreće pozornost na kontinuirani rast povrata u ukupnom broju osuđenih osoba u našoj zemlji, koji se kretao od 8,4 \% 1998. godine do čak 29,6 \% 2010 godine. Parlamentarna je skupština Vijeća Europe 2006. godine donijela Preporuku 1741- Socijalna reintegracija zatvorenika, konstatirajući da zatvorska kazna u mnogim članicama Europske unije ne ostvaruje jedan od svojih osnovnih ciljeva, u smislu pripreme zatvorenika za socijalnu reintegraciju budući da je velik broj otpuštenih zatvorenika ponovno počinio kazneno djelo unutar pet godina od otpusta iz zatvora (Parliamentary Assembly, 2006).

Mejovšek (1995) u analizi rezultata provedenog istraživanja na uzorku od 327 zatvorenika iz Kaznionice u Lepoglavi, ističe da posebnu pozornost zaslužuje određeni postotak osoba s negativnim obilježjima ličnosti (primarno psihopatskima), koji su najčešće multirecidivisti i kod kojih je prognoza uspješne resocijalizacije znatno nepovoljnija u odnosu na preostali dio zatvorske populacije. Zahtjevnost rada s osobama kod kojih je prisutan asocijalni poremećaj ličnosti, potvrđena je nizom istraživanja (Mejovšek, 2002).

U odnosu na opću populaciju, dva do četiri puta je vjerojatnije da će zatvorenici imati psihotične ili izražene depresivne poremećaje (Fazel i Danesh, 2002; prema Butorac i sur., 2017). Zatvorenici ovisni o drogama i o alkoholu predstavljaju posebno zahtjevan dio zatvorske populacije, a u značajnijem su udjelu prisutni u zatvorskoj populaciji (Doležal i Jandrić, 2002; MacDonald i sur., 2013). Općenito imaju visoke stope kriminalne aktivnosti i čine disproporcionalne količine svih vrsta kaznenih djela, što je osobito potrebno imati u vidu (Marlowe, 2002; prema Maloić, Mažar i Jandrić Nišević, 2013). Nadalje, sve veći postotak zatvorenika je starije životne dobi, dok se istovremeno radi o "skrivenom" i nedovoljno prepoznatom dijelu zatvorske populacije (Lewis, 2013; Crawley, 2004).

\section{Izazovi povratka u zajednicu}

Vezano uz otpuštanje zatvorenika u zajednicu, u literaturi se upozorava na dvije ključne činjenice koje je potrebno imati u vidu (Travis i sur., 2001; Taxman, 2004):

(1) građani od državnih institucija i službi očekuju osiguravanje uvjeta u okviru kojih će povratak zatvorenika biti siguran, na način da neće počiniti novo kazneno djelo u njihovoj zajednici

(2) povratak u zajednicu je složen proces jer je otpušteni zatvorenik na određeni način uhvaćen u mrežu svojih socijalnih, ekonomskih i psiholoških potreba.

Otpust iz zatvora je univerzalno iskustvo svih koji su prema bilo kojoj osnovi boravili u zatvoru; bilo da su bili uhićeni, optuženi ili osuđeni i nakon toga pušteni iz zatvora (Travis, 2000). Proživljeno iskustvo s izvršavanja kazne zatvora ne nestaje s danom otpusta iz zatvora (O'Neill, 2017). Rezultati istraživanja pokazuju da zatvorenici koji izvršavaju kraće zatvorske kazne nerijetko imaju iste poteškoće (gubitak integriteta u trenutku otpusta, materijalni gubitci, problemi sa zapošljavanjem i podrškom obitelji, poteškoće povezane sa suprugom i djecom, psihološke poteškoće), ali različita stupnja (Décarpes i Durnescu, 2014). Proces prilagodbe prvih dana i mjeseci na otpust 
iz zatvora i povratak u zajednicu sve se više ističe kao kritično razdoblje za osobe koje izlaze iz zatvora (McNally i Brennan, 2015).

Nakon otpusta mogu se javiti različite poteškoće prilagodbe, koje su kod žena i izraženije prisutne (Dodge i Pogrebin, 2001, prema O'Neill, 2017; Loucks, 2004, prema O'Neill, 2017; O'Neill, 2017):

(1) osjećaj gubitka i dezorijentiranosti prvih dana i tjedana nakon otpusta

(2) strah od susreta s poznatim ljudima, uz osjećaje krivnje i srama

(3) jednostavne aktivnosti kao što su na primjer odlazak u trgovinu ili korištenje javnog prijevoza mogu izazivati veliki stres.

Način nošenja s "neprijateljskim i zbunjujućim svijetom" može biti povlačenje u svoj dom, što dovodi do izolacije i socijalne isključenosti i povećava rizik ponovnoga počinjenja kaznenog djela (Dodge i Pogrebin, 2001; prema O'Neill, 2017).

Glavnim su stresnim događajima povratka zatvorenika na slobodu, istraživanjem koji su proveli Zamble i Porporino (prema Mejovšek, 2002, 56), prepoznati: sukobi i svađe sa suprugom ili partnericom, financijske potrebe, sukobi s prijateljima, nezadovoljstvo načinom života, problemi s policijom i ograničenja nametnuta probacijom, usamljenost ili depresija, problemi na poslu, konzumiranje droga i alkohola, nezaposlenost ili neodgovarajuće zaposlenje i neizvjesnost vezana za vlastitu budućnost. Utvrđeno je da su otpušteni zatvorenici probleme nastojali riješiti odmah, bez plana, na impulzivan način, bez dovoljno motivacije i ustrajnosti.

Istraživanja pokazuju da zatvorenici uobičajeno trebaju pomoć vezanu uz promjenu stavova, razmišljanja i ponašanja, smještaj, zapošljavanje, zdravlje, financije, obiteljske odnose i ovisnost (Markson, Lösel, Souza i Lanskey, 2015). Istraživanje provedeno u Nizozemskoj, a usmjereno na prepoznavanje potreba otpuštenih zatvorenika, pokazuje da je $22 \%$ njih imalo problem s pribavljanjem identifikacijskih dokumenata, $40 \%$ nije imalo nikakav dohodak, $30 \%$ ih je imalo probleme povezane sa stanovanjem i $8 \%$ je imalo probleme povezane sa zdravljem (Kuppens i Ferverda, 2008; prema Hermans, 2009).

Istraživanje provedeno u Srbiji 2014. godine (Srnić i Vulević, 2016) donijelo je neka bitna obilježja zatvorenika obuhvaćena istraživanjem, a koja u znatnoj mjeri mogu predstavljati prepreke reintegraciji u društvo nakon otpusta:

(1) većina zatvorenika je bila pismena, 26,7 \% je završilo osnovnu školu, više od 1/2 srednju; uočen je problem funkcionalne nepismenosti, odnosno nesnalaženje u korištenju novih tehnologija

(2) preko 1/2 imalo je probleme povezane s ovisnošću, pri čemu je dominirala ovisnost o drogama

(3) 1/5 nije imala posjete tijekom izvršavanja kazne zatvora ni bilo kakvu financijsku podršku te su bili bez oslonca bliskih osoba nakon izlaska na slobodu 
(4) $81 \%$ ispitanika izrazilo je namjeru aktivna traženja posla putem obitelji i prijatelja - kao najveću prepreku u pronalaženju zaposlenja navodili su osuđivanost i stigmu

(5) $1 / 2$ zatvorenika nije imala vrijedeću osobnu iskaznicu

(6) određeni broj zatvorenika nije znao gdje će prijaviti prebivalište nakon izlaska na slobodu i očekivali su poteškoće s obzirom na društvene predrasude.

Istraživanje koje su proveli Mahmutović i Hasanbegović (2007) pokazalo je da polovica (49\%) zatvorenica obuhvaćenih istraživanjem nije imala pozitivan stav o postpenalnoj pomoći u Federaciji BiH i nisu očekivale nikakvu pomoć. Nakon provedenog istraživanja vezanoga uz očekivanja zatvorenika i zatvorenica u Kaznionici u Požegi o životu nakon izlaska iz penalne ustanove, Markač (2016) dolazi do zaključka da većina njih zamišlja da će im život na slobodi izgledati jednako kao i prije dolaska u kaznionicu, bez konkretnijih očekivanja i planova za budući život. Vidmar (2016) je poslijepenalnu zaštitu u Sloveniji u određenoj mjeri ocijenila neadekvatnom, utvrđujući postojeće intervencije i usluge nedostatnima, a ponekad i zakašnjelima. Razmatrajući mogućnosti poboljšanja poslijepenalne zaštite u Sloveniji Kobal i Žakelj (2007) su posebno upozorili na otpuštene zatvorenike kao na ranjivu skupinu na području rada, zbog dulje odsutnosti s tog područja i nerijetko smanjenih radnih sposobnosti, ali posebno zbog stigme zbog koje često imaju poteškoće pri traženju posla i zapošljavanja.

Dio se zatvorenika vraća u zajednicu uz prisutne određene psihičke tegobe i neadekvatne strategije nošenja s teškoćama (Listwan, Cullen i Latessa, 2006). Dostupan im je vrlo mali broj poslova, a zbog manjka vještina i kvalifikacija, ti su poslovi češće honorarni, privremeni, pomoćni i slabije plaćeni (Sarno, Hearnden, Hedderman, Hough, Nee i Herrington, 2000). Suočavaju se s nizom osobnih i birokratskih problema, uključujući financije, uz poteškoće obnavljanja roditeljske, partnerske i drugih pozitivnih uloga (Maloić i Rajić, 2012). Rjeđe raspolažu s dovoljno novaca za plaćanje stanovanja, a ponekad više nisu dobrodošli u svojim obiteljima (Travis i sur., 2001). Posebno je zahtjevna socijalna reintegracija ovisnika, pripadnika etničkih manjina i starijih osoba, s obzirom na njihove specifične potrebe (Crawley, 2004; Doležal i Jandrić, 2002; Nugent i Pitts, 2009). Do problema u reintegraciji mogu dovesti i etiketiranost bivših zatvorenika i stigma (Nugent i Pitts, 2009). Već odavno je prepoznat rizik da bivši zatvorenici budu marginalizirani ili isključeni, bilo kao rezultat njihova ponašanja ili straha zajednice od njih (McNally i Brennan, 2015). Problem je i što zatvorenici često ne znaju na što sve imaju pravo ili koje bi usluge mogli dobiti u zajednici (Nugent i Pitts, 2009).

Parlamentarna skupština Vijeća Europe kao glavne razloge kriminalnog povrata navodi: neuspjeh zatvora da otpuštenim zatvorenicima organiziraju značajniju pomoć u njihovoj potrebi za poslom i smještajem, nedostatak obrazovanja i radnog osposobljavanja, manjak obiteljske podrške, prizonizaciju i društvene predrasude (Parliamentary Assembly, 2006). Manjak resursa, komunikacije i koordinacije unutar kaznenopravnog sustava, kao i ovog sustava s drugim sustavima, može dovesti do otpusta zatvorenika bez njegove povezanosti s uslugama podrške i pomoći u zajednici koje bi mu pružile institucije, ili nevladin sektor, što se ocjenjuje vrlo rizičnim (Griffiths i sur., 2007). Kod određenog broja zatvorenika koji su odbijali, ili su ostali neprijemčivi za tretmanska nastojanja, ili se iz drugih razloga procjenjuju visokorizičnima (odnosno opasnima) za društvo, otpust iz zatvora 
u maksimalno mogućoj mjeri zahtijeva pozornost i međusektorsku suradnju (Maguire, Kemshall, Noaks, Wincup i Sharpe, 2001; Probation Board for Northern Ireland, 2017; Ministry of Justice, 2018).

\section{Učinak neuspjele reintegracije na pojedince i društvo u cjelini}

Koller-Trbović i Mirosavljević (2005) upozoravaju da nastavak rada u zajednici predstavlja posljednju kariku u lancu interventnih mjera na kriminalno ponašanje, pri čemu neadekvatan pristup i propusti u bilo kojoj od interventnih mjera mogu poništiti pozitivna postignuća prethodnih. Knežević (2011) zaključuje da je neuspjeh učinkovite reintegracije zatvorenika ujedno i neuspjeh cjelokupnog izvršavanja kazne zatvora. S obzirom na uvijek prisutnu mogućnost ponavljanja kaznenog djela, povratak zatvorenika u zajednicu dovodi do zabrinutosti javnosti, izazov je za praktičare i zakonodavce, pri čemu je glavno pitanje kako prevenirati ponovno počinjenje kaznenog djela (Žakman Ban, 1992; Denney, Tewksbury i Jones, 2014).

Čak i kad nema individualne žrtve, ne postoji kazneno djelo bez žrtve (Basile, 2002). Shapland i Hall (2007) potvrđuju da učinci kaznenog djela na žrtve (i na individualne i na pravne osobe) mogu biti višestruki, uključujući između ostalih psihološku, mentalnu, socijalnu, fizičku i financijsku štetu (primjerice, šok i gubitak povjerenja u društvo, a naročito u lokalnu zajednicu, fizičke ozljede, financijski gubitak, strah, ljutnju, depresiju, promjenu životnog stila, preseljenje). Sve te posljedice imaju učinak i na obitelj žrtve, a posebice je traumatičan ishod za obitelj smrt žrtve. Žrtve (i posredno njihove obitelji) su osobito teško pogođene u sljedećim situacijama:

— kada su bile suočene sa smrću

— ako su se dugo vremena nalazile pod nasilnom kontrolom počinitelja

— u slučaju fizičkoga, seksualnog ili psihičkog zlostavljanja

— ako je žrtva bila uključena u dugotrajne i intenzivne svađe

— kada je došlo do zadiranja u intimnu sferu, primjerice stan osobe, bazu osobnih, intimnih i povjerljivih podataka i slično (Borovec i Burazer, 2007).

Povratak zatvorenika u zajednicu donosi mogućnost ugroze ranijih žrtava, novih žrtava, dakle novu opasnost za društvo, ljude, objekte, sredstva i vrijednosti koje su ugrožene kriminalnim ponašanjem (Probić, 1997; prema Žakman-Ban, 1992). Razina povjerenja građana u kaznenopravni sustav umanjuje se svakim počinjenjem kaznenog djela bivšeg zatvorenika i dovodi do nesigurnosti u društvu (Borovec i Burazer, 2007; United Nations Office on Drugs and Crime, 2012). Ponovno uključivanje u društvo može, osim do ponovnog počinjenja kaznenog djela, dovesti i do (Petersilia, 2000; Travis i sur., 2001; Petersilia, 2001; Maloić, 2013; MacDonald i sur., 2013):

— javnozdravstvenih rizika (konzumiranje droga, beskućništvo i tako dalje)

— narušavanja obiteljskih odnosa i obiteljskih problema

— zakazivanja djece u obrazovnom procesu i pojave poremećaja u ponašanju

— zdravstvenih problema zatvorenika, odnosno članova obitelji (na primjer, potreba za psihijatrijskim tretmanom) 
— kršenja zakonskih propisa iz prekršajne domene.

Zatvorenici se nakon otpusta suočavaju sa stvarnim i složenim izazovima, pri čemu rizik za zajednicu raste ako se otpuštaju bez adekvatne pripreme, supervizije ili podrške (United Nations Office on Drugs and Crime, 2012). MacDonald i sur. (2013) ističu da učinkovita poslijepenalna zaštita ima pozitivan učinak na recidivizam i da se na taj način mogu spriječiti nove žrtve i nova zatvaranja počinitelja. Nadalje, izvršavanje zatvorskih kazni iziskuje velika materijalna sredstva, pri čemu su potrebna ulaganja i u prevladavanje negativnih posljedica zatvaranja, a ta se sredstva mogu utrošiti na različite potrebne sadržaje u društvu, kao na primjer za izgradnju škola ili vrtića (Maloić, 2013; Butorac i sur., 2017). Prevencijom povratništva koristi se postižu i na područjima obrazovanja, zapošljavanja, zdravstva i socijalne skrbi (Welsh, 2004).

U smjeru prevencije kriminalnog povrata angažman države je ključan. Primjerice, norveška vlada garantira maksimalno moguće osiguranje da se otpuštenom zatvoreniku omogući stanovanje, zaposlenje, obrazovanje, zdravstvena skrb, tretman ovisnosti i ostalo potrebno u svrhu njegove reintegracije u društvo (Butorac, Gracin i Stanić, 2017). Ured za droge i kriminal Ujedinjenih naroda (United Nations Office on Drugs and Crime, 2012) usvajanje mjera kojima se osigurava učinkovita reintegracija zatvorenika u zajednicu vidi najboljim i najisplativijim načinom prevencije kriminalnog povrata. $U$ tom se smjeru naglašava da svaka strategija prevencije kriminala treba obuhvatiti i problem povratništva, to jest uzeti u obzir činjenicu da na sigurnost društva utječe velik broj kaznenih djela koje su počinile ranije osuđivane osobe. Ignoriranje potrebe investiranja u socijalnu reintegraciju i reintegracijske procese ocjenjuje se skupim izborom, budući da svako kazneno djelo donosi troškove koji mogu biti značajni, kao što su troškovi istrage, kaznenog progona i suđenja, troškovi zatvaranja te troškovi koji zahvaćaju žrtve i zajednice. Činjenica da pojedine države ponekad oklijevaju s prijedlozima osiguravanja usluga i pomoći otpuštenim zatvorenicima koje moguće nisu uobičajeno dostupne i svim građanima, razmatra se sa stajališta sigurnosti zajednice, to jest zaključuje se da pomoć u reintegraciji nije nužna samo za dobrobit otpuštenog zatvorenika, već i za sigurnost zajednice, budućih žrtava i za cjelokupni socioekonomski razvoj zemlje. Zastupa se sveobuhvatni strateški pristup uz uključivanje svih koji reintegraciji mogu pridonijeti. Uz apostrofiranje potrebe analize zakonskih propisa, koji mogu biti ograničavajući, nude se prakse dokazane i obećavajuće učinkovitosti, koje bi bilo uputno razmotriti u nekim budućim radovima.

\section{UČINKOVITOST POSLIJEPENALNE ZAŠTITE}

Paradigma Što funkcionira? (engl. What works?) nastala je kao reakcija na Martinsonove tvrdnje 1974. godine i smjer Ništa ne funkcionira (engl. Nothing works) u rehabilitaciji počinitelja kaznenih djela (Kanduč, 1996; Cullen i Gendreau, 2001; Mejovšek, 2001, Maloić i sur., 2013). U nastavku rada sažeto će se prezentirati neke dokazane spoznaje vezane uz pristupe kažnjavanju, izvršavanju kazne zatvora i vraćanju zatvorenika u zajednicu.

\section{Pristupi kažnjavanju i izvršavanju zatvorske kazne}

Odabrani pristupi kažnjavanju mogu osim željenih, donijeti i neželjene posljedice, pri čemu pristupi ne utječu samo na počinitelja kaznenog djela, već učinke mogu imati i na obitelji, susjedstva i zajednice (Petersilia, 2004; Maloić, 2013). Nadalje, neka intervencija može koristiti društvu na kratak 
rok i smanjiti recidivizam, ali imati negativne posljedice u duljem razdoblju (Šućur, 2001). Ključnom svrhom ulaganja u učinkovitu poslijepenalnu zaštitu, posebice u reintegraciju počinitelja kaznenih djela, smatra se smanjivanje rizika za ponovno počinjenje kaznenog djela i povećanje sigurnosti zajednice (Serin i sur., 2010). Danas već postoje jasni rezultati istraživanja koji ukazuju da kažnjavanje, primarno usmjereno na izolaciju i onemogućivanje činjenja kaznenih djela, te na kontrolu, nadzor i praćenje, ne daje željene rezultate (Travis i sur., 2001; Petersilia, 2004; Griffiths i sur., 2007; Butorac i sur., 2017). Lipsey je (1992; prema Mikšaj-Todorović, Buđanovac i Brgles, 1998), dokazao i da programi temeljeni samo na kažnjavanju, kao što su šok-zatvaranje i intenzivni nadzor, u prosjeku povećavaju recidivizam za 25 \% u odnosu na kontrolne skupine. Jasno je da je kod određenog broja počinitelja, s obzirom na kazneno djelo i/ili povratništvo, izdvajanje iz zajednice nužno, da bi in se onemogućilo u ponavljanju kaznenog djela (Maloić, 2013). Jasno je i samo po sebi da osoba u zatvoru ne može biti prijetnja za društvo tijekom vremena izvršavanja kazne zatvora (Kovčo, 1997). Međutim, proces zatvorenikova mijenjanja i prilagodbe društvu ne događa se samo kao posljedica zatvaranja na određeno vrijeme, to jest, zatvaranje samo po sebi ne socijalizira ljude (Basile, 2002; Uzelac, Žakman-Ban i Farkaš, 2008). Samo poslijepenalna zaštita usmjerena na dugoročne ciljeve reintegracije može dovesti i do dugoročnih koristi za društvo u cjelini (Travis i sur., 2001; Latessa i Lovenkamp, 2006). Pri tome, zatvaranje, nadzor i praćenje u kombinaciji s tretmanom i uslugama mogu dodatno smanjiti rizik kriminalnog povrata, sve dok naglasak ostaje primarno na socijalnoj reintegraciji (Griffiths i sur., 2007).

Na europskom je području, pa tako i u našoj zemlji, dominantan rehabilitacijski pristup u postupanju s počiniteljima kaznenih djela, temeljem dokaza njegove učinkovitosti (Petersilia, 2004; Andrews, Bonta i Wormith, 2006; Latessa i Lowenkamp, 2006; Bonta i Andrews, 2012). Postojeća istraživanja nedvojbeno pokazuju da intervencije koje se baziraju na pristupu Što funkcionira? (engl. What works?) i Modelu rizik - potreba - responzivnost to jest RPR modelu (engl. Risk - need - responsivity model, RNR Model), učinkovito smanjuju recidivizam (Durnescu, 2011; Décarpes i Durnescu, 2014; James, 2018), a postoje i empirijski dokazi učinkovitosti paradigme prestanka i odvraćanja od činjenja kaznenih djela (engl. desistance paradigm) i Modela kvalitetnih života, MKŽ (engl. Good lives model, GLM Model (MacDonald i sur., 2013, Maruna 2017). RPR i MKŽ su komplementarni modeli i pružaju solidnu bazu za prestanak činjenja kaznenih djela i uspješnu socijalnu reintegraciju počinitelja (Ward, Yates i Willis, 2012). Oba su pristupa već prikazana u domaćoj stručnoj literaturi (Maloić, 2016) te ih se stoga u ovom radu neće detaljnije prikazivati i analizirati. Tema rada nužnim ipak nalaže istaknuti načelo rizika RPR modela. Naime, dokazano je da je zatvorenicima s procijenjenim višim rizikom potrebno osigurati intenzivniji tretman i usluge, to jest da se napori i resursi trebaju usmjeriti prema onima kod kojih postoji najveća vjerojatnost počinjenja novoga kaznenog djela (James, 2018; Mejovšek, 2002). Provedena istraživanja u okviru paradigme Što funkcionira? svakako govore u prilog tezi da koristi programa poslijepenalne zaštite nadmašuju troškove samih programa i usluga (Welsh, 2004).

\section{Izvršavanje kazne zatvora}

Potrebu ranog rada i planiranja otpusta sa zatvorenicima temeljem rezultata istraživanja ističe više autora, pri čemu se bitnim naglašava rani razvoj integracijskog plana usmjerenog na razvoj vještina i povezivanje sa sadržajima u zajednici nakon otpusta (Décarpes i Durnescu, 2014; 
MacDonald i sur., 2013; Petersilia, 2004). U radu sa zatvorenicima nužnim je potvrđeno (Brinc, 1986; prema Mikšaj-Todorović i Buđanovac, 2001; Burnett i Maruna, 2006; Connor, Copes i Tewksbury, 2011; Listwan i sur., 2006; MacDonald i sur., 2013; Maguire, 2011; Maguire i Raynor, 2006; Maloić, 2016; McAliden, 2016; Mejovšek, 2002; Serin i sur., 2010; Taxman, 2004):

(1) imati u vidu različita obilježja zatvorenika

(2) uzimati u obzir sve tri komponente načela responzivnosti - opću, specifičnu i sustavnu

(3) raditi na buđenju i održavanju motivacije za promjenom

(4) uključiti zatvorenika, uzimati u obzir njegove osjećaje, njegovu percepciju vlastitih potreba i sadržaja tretmana

(5) usmjeravati zatvorenika na preuzimanje odgovornosti, raditi na promjeni načina razmišljanja i stavova

(6) uvažavati zaštitne čimbenike i graditi na snagama zatvorenika.

Kao važni elementi učinkovitosti reintegracije zatvorenika potvrđeni su klasifikacija i postojanje tretmanskih programa (Damjanović i sur., 2001; Durnescu, 2011; James, 2018; Mejovšek, 2001). Naglašava se značaj posebnih tretmanskih programa namijenjenih primjerice ovisnicima, počiniteljima nasilja, specifično počiniteljima obiteljskog nasilja, počiniteljima seksualnih delikata i programa specifično usmjerenih na razvoj kognitivnog funkcioniranja i različitih socijalnih vještina (komunikacijske vještine, samokontrola, kritičko i kreativno mišljenje, rješavanje problema) - sve je programe potrebno provoditi na učinkovite načine, evaluirati i unapređivati (Bakić, 2001; Connor i sur., 2011; Duwe, 2015; Griffiths i sur., 2007; McAlinden, 2016; Mikšaj-Todorović, Buđanovac i Brgles, 1998; Raynor i Robinson, 2009). Rezultatima je istraživanja primjerice potvrđeno da su osuđenici s problemom ovisnosti o drogama, koji su bili uključeni u tretman u zatvoru i nakon otpusta, bili uspješniji u apstinenciji i manje su uhićivani (MacDonald i sur., 2013; Travis, 2000). Kao jedan od primjera projekata kojima se nastoji uzeti u obzir specifičnosti zatvorenika s problemom ovisnosti o drogama, može se istaknuti Projekt resocijalizacije ovisnika o drogama, koji se od 2007. godine provodi u našoj zemlji (Ured za suzbijanje zlouporabe droga, 2015). U literaturi se učestalo ponavlja i potvrđuje i nužnost specifičnih načina rada s vulnerabilnim skupinama tijekom zatvorske kazne i nakon izvršavanja kazne zatvora, primjerice sa ženama, starijima, pripadnicima manjinskih skupina i slično, zbog njihovih specifičnih potreba u odnosu na ostatak zatvorske populacije (Cuéllar, Tortosa, Dreckmann, Markov, Doichinova, 2015; Penić i sur., 2017; United Nations Office on Drugs and Crime, 2012).

Evans (2005; prema Koller-Trbović i Mirosavljević, 2005) navodi listu dokazanih potreba o kojima je potrebno voditi računa: dokumenti, stambeno pitanje, pomoć u obliku prehrane, odjeće, zdravstvena zaštita, zaposlenje, savjetovanje, općenito sustav podrške u zajednici u koju se osoba vraća. Utvrđeno je da su programi usmjereni na strukovno obrazovanje i rad zatvorenika učinkoviti u smanjivanju recidivizma (Décarpes i Durnescu, 2014; Nugent i Pitts, 2009; Seiter i Kadela, 2003). Strukovno obrazovanje djeluje posredno na učinkovitiju socijalnu reintegraciju putem uspješnijeg zapošljavanja. Kao potvrdu, Petrović i Jovanić (2019) donose niz istraživanja u prilog afirmativnoj povezanosti obrazovanja tijekom zatvorske kazne i smanjenja kriminalnog povrata. Istraživanjem 
provedenim u Srbiji (Stevanović i sur., 2018) vezano uz utjecaj stručnog osposobljavanja zatvorenika na penološki povrat, nije utvrđena statistički značajna razlika između kriterijske i kontrolne skupine. Zaključeno je da samo strukovno osposobljavanje ne može biti dovoljno, ali može biti snažna podloga za postpenalnu pomoć, dok se glavnim problemom navodi nedostatna postpenalna pomoć otpuštenim zatvorenicima u različitim segmentima pa tako i vezano uz zapošljavanje.

U radu sa zatvorenicima ne pokazuje se učinkovitim samo rad na pojedinim kriminogenim potrebama, već je utvrđeno da pristup zatvoreniku treba biti holistički. Potrebno je odgovoriti i na emocionalne i na socijalne aspekte života, pri čemu je važno razvijati i ljudski i socijalni kapital (Denney i sur., 2014; Maguire i Raynor, 2006; McNeill, 2006). Serin i sur. (2010) navode da istraživanja potvrđuju obiteljsko stanje i prosocijalnu podršku važnim čimbenicima za prestanak činjenja kaznenih djela. Posebno se važnim smatra zadržavanje pozitivnih veza između zatvorenika i njihovih obitelji tijekom kazne zatvora (O'Neill, 2017). Dokazano je da posjeti zatvorenicima imaju određen pozitivan učinak na smanjenje kriminalnog povrata, ali se ponajprije upozorava na potrebu daljnjih istraživanja u smjeru učestalosti posjeta, osoba koje dolaze u posjet i slično (Mears, Cochran, Siennick i Bales, 2012). Visher i Travis (2003) takva istraživanja cijene nužnima, temeljem dokazane važnosti socijalnog kapitala za zatvorenike tijekom i nakon zatvaranja. Povezanost kvalitetnih obiteljskih odnosa s općom procjenom ponašanja u zatvoru i s prognozom uspjeha resocijalizacije potvrdio je i Šućur (1995).

Veliki se značaj u literaturi daje i međusektorskom pristupu i uključivanju nevladina sektora u poslijepenalnu zaštitu, pri čemu se posebno ističe (Denney i sur., 2014; Koller-Trbović i Mirosavljević, 2005; LaVigne i sur., 2006; McNally i Brennan, 2015; Nugent i Pitts, 2009; Penić i sur., 2017; Previšić i Leko, 1988; Travis, 2000):

— institucije/službe bi trebale raditi zajedno u partnerstvu uz učinkovitu komunikaciju

— na ključne potrebe u okviru socijalne reintegracije zatvorenika moguće je odgovoriti i angažmanom nevladina sektora

— značajniju ulogu vezano uz poslijepenalnu zaštitu trebali bi imati i suci

— u poslijepenalnu zaštitu svakako treba biti uključena i policija, imajući u vidu manji ili veći stupanj vjerojatnosti za počinjenje novog kaznenog djela.

\section{Povratak u zajednicu}

Povratku zatvorenika u zajednicu treba prethoditi tretmanski rad tijekom izvršavanja kazne i neposredna priprema zatvorenika za otpust. Na primjer, Listwan, Cullen i Latessa (2006) pojašnjavaju da počinitelju kaznenog djela nije dovoljno samo osigurati posao nakon povratka jer će od njega brzo odustati, ako mu se prethodno ne pomogne u kognitivnom razvoju, stjecanju radnih navika i razumijevanju posljedica njegova ponašanja.

Otpust iz zatvora donosi opasnost od počinjenja novoga kaznenog djela, ali i jedinstvenu priliku za daljnji rad na ostvarivanju socijalnih ciljeva kazne (Travis, 2000). Trenutak otpusta, kao i sati i dani koji slijede, mogu biti od glavnog značaja za učinkovitost procesa reintegracije počinitelja. 
Travis i sur. (2001) upozoravaju da bi sustavna pažnja trebala biti posvećena malim detaljima, kao što je primjerice dio dana kada se zatvorenik otpušta.

Décarpes i Durnescu (2014) analiziraju rezultate više istraživanja kojima je dokazano da su ishodi otpuštenih zatvorenika daleko bolji ako rad u zatvoru prati nastavak rada u zajednici. Upozoravaju da nije bitna samo priroda intervencije, nego i kada su te intervencije dostupne, kojeg su intenziteta i trajanja, gdje im se, kada i kako može pristupiti i tako dalje. Primjerice, Hipp i suradnici (2010, prema Décarpes i Durnescu, 2014) utvrdili su da prisutnost pružatelja socijalnih usluga u zajednici unutar dviju milja dovode do niže stope povratništva. Prijevoz se sve češće ističe kao važan čimbenik u socijalnoj reintegraciji (Denney i sur., 2014; Evans 2005; prema Koller-Trbović i Mirosavljević, 2005; Listwan i sur., 2006). Istraživanja pokazuju da uključivanje predstavnika manjina u osoblje koje se bavi poslijepenalnom zaštitom nakon otpusta pomaže u zadržavanju kontakata s otpuštenim zatvorenicima pripadnicima manjina (Décarpes i Durnescu, 2014).

Rezultati istraživanja pokazuju da motivacija zatvorenika, odnosno otpuštenih zatvorenika može biti u bitnome smanjena zbog problema sa stanovanjem i financijskih problema (MacDonald i sur., 2013). Vezano uz obrazovanje i zapošljavanje zatvorenika, odnosno otpuštenih zatvorenika, dvije su važne spoznaje: (1) vještine i znanja trebaju biti povezani s aktualnim potrebama na tržištu rada i (2) nužna su jaka partnerstva i suradnja između agencija da bi zatvorenici mogli dobiti potrebnu podršku i usluge (Sarno i sur., 2000). Istraživanja pokazuju da rizik od ponovnog počinjenja kaznenog djela raste s vremenom potrebnim otpuštenim zatvorenicima da riješe određene probleme, na primjer da nađu posao (Travis i sur., 2001; Welsh, 2004). Usluge i prilike koje na raspolaganju stoje otpuštenim zatvorenicima svakako ovise i o socioekonomskim uvjetima u pojedinoj zemlji. $\mathrm{U}$ prilog navedenom govori i činjenica da se skandinavske zemlje zbog niske stope recidivizma navode primjerom za učinkovito provođenje poslijepenalne zaštite, pri čemu treba uzeti u obzir da se radi o zemljama s razvijenim sustavom obrazovanja i socijalne skrbi i s najmanjom razlikom između bogatih i siromašnih (Butorac, Gracin i Stanić, 2017). Zapošljavanje otpuštenih zatvorenika može biti olakšano u situacijama kada je stopa nezaposlenosti u državi niža, kao što je to bilo u našoj zemlji posljednjih godina (Laušić, 2020), iako predrasude i stigma uvijek mogu predstavljati prepreku. No, zapošljavanje je dodatno otežano kada je stopa nezaposlenosti u društvu visoka, kao što je to bilo tijekom globalne financijske krize koja je ne tako davno uzrokovala visoke i trajne stope nezaposlenosti u cijeloj Europskoj uniji (Logarušić i Raguž Krištić, 2019). U narednom razdoblju na nacionalnoj će razini posebni izazovi biti novi veliki porast nezaposlenosti zbog pandemije Covida-19 te negativne socioekonomske posljedice koje se tek očekuju (Hrvatski zavod za zapošljavanje, 2020), a što će zacijelo imati negativan učinak i na mogućnost zapošljavanja otpuštenih zatvorenika i dostupnost njima potrebnih usluga pa će time svakako biti potreban dodatan angažman države.

Jedan je od velikih problema zapošljivosti otpuštenih zatvorenika stigmatizacija i nepovjerenje potencijalnih poslodavaca, kada otpušteni zatvorenici bez adekvatnog zaposlenja i prihvaćanja društvene zajednice u velikom broju recidiviraju (Petrović i Jovanić, 2010). Istraživanje koje su Mikšaj-Todorović i Buđanovac (2000) proveli u razdoblju od ožujka 1997. do ožujka 2000. godine pokazalo je uglavnom pozitivne stavove hrvatskih građana prema bivšim zatvorenicima i rehabilitaciji. Ispitivanje stavova je pokazalo da muškarci, mladi ljudi, educiraniji ljudi i ljudi iz većih gradova imaju pozitivnije stavove, dok je uočena potreba za educiranjem drugih skupina s negativnijim stavovima - starijima, manje educiranima, iz ruralnih područja. Istraživanjem je utvrđeno i da više 
od 50 \% građana ne iskazuje negativne predrasude, prihvaća mogućnost osobne pomoći bivšem zatvoreniku na povratku u zajednicu, ima pojam o rehabilitativnim ciljevima zatvorske kazne, dok su se ispitanici češće negativno izjasnili vezano uz življenje $u$ istom stanu s bivšim zatvorenikom (Buđanovac i Mikšaj-Todorović, 2002). Istraživanje koje je provela Veić (2016) na 137 korisnika društvene mreže Facebook, pokazalo je da:

— većina ispitanika ne zna da je svrha izvršavanja kazne zatvora osposobljavanje zatvorenika za život na slobodi u skladu sa zakonom i društvenim pravilima, a ne samo kažnjavanje

— postoji veliko nezadovoljstvo ispitanika naspram zatvoreničkoj populaciji, pri čemu smatraju da zatvorenici u Hrvatskoj uživaju mnoga prava i privilegije.

Vremenski razmak u provođenju i razlika u rezultatima istraživanja mogli bi upozoravati na promjenu stavova hrvatskih građana prema (otpuštenim) zatvorenicima i mogućnostima reintegracije. Na stvaranje straha u zajednici posebno velik učinak može imati senzacionalistički pristup izvještavanju medija o kriminalitetu, što potom dovodi i do stavova o potrebi za strožom kaznenom politikom i izdvajanjem počinitelja iz zajednice (Đoković, 2019). Situacija da su političke strukture na nesigurnost građana, izazvanu visokopubliciranim slučajevima i medijskim senzacionalističkim prikazima kriminala, reagirale pooštravanjem zakona već su prepoznate u našoj zemlji, a što zasigurno potom ima učinak i na spremnost zajednice za odgovor na potrebe otpuštenih zatvorenika (Maloić, 2013).

U svojoj metaanalizi gotovo 400 istraživanja Lipesy (1995, prema Décarpes i Durnescu, 2014) je zaključio da je zaposlenje najvažniji čimbenik koji smanjuje recidivizam. I drugi autori zapošljavanje ističu kao prvi zahtjev učinkovite socijalne reintegracije (Gills i sur., 1996, prema Hurry, Brazier, Parker i Wilson, 2006; Davis i sur., 2008, prema Woodier, 2013; MacDonald i sur., 2013; Woodier, 2013). Istraživanja su također pokazala i da neformalna mreža ima bitnu ulogu u nalaženju zaposlenja više od 60 \% bivših zatvorenika koje je intervjuirao La Vigne sa suradnicima (2006), izjavilo je da su posao nakon otpusta našli razgovarajući s članovima obitelji, rođacima i prijateljima. DiZerega (2010) ističe da su obitelji prirodan resurs u procesu reintegracije otpuštenog zatvorenika - mogu pružiti razumijevanje i emocionalnu podršku, financijsku pomoć, smještaj i brigu o djeci. Nadalje, rezultati istraživanja dovode do spoznaje da je za uspješno povezivanje otpuštenog zatvorenika sa zajednicom nužno da država, zajednica i volonterske organizacije rade zajedno u partnerstvu da bi se postigla stvarna promjena u životima otpuštenih zatvorenika (McNally i Brennan, 2015).

\section{DOMINANTNI IZAZOVI I PREPORUKE}

Tri su dominantna izazova poslijepenalne zaštite na koja se čini važnim pokušati odgovoriti: (1) kako osigurati socijalnu reintegraciju zatvorenika uz što manju ugrozu zajednice, (2) što kada otpušteni zatvorenik unatoč naporima počini novo kazneno djelo i (3) kako povećati interes i uključenost svih koji mogu doprinijeti učinkovitosti socijalne reintegracije zatvorenika.

Vezano uz prvi izazov, pregledom literature i u radu prezentiranih spoznaja, evidentno je (Bonta i Andrews, 2012; Butorac, Gracin i Stanić, 2017; Décarpes i Durnescu, 2014; Griffiths i sur., 2007; James, 2018; Latessa i Lovenkamp, 2006; Maloić, 2016; Petersilia, 2004; Travis i sur., 2001; Welsh, 2004): 
— rehabilitacijski pristup pokazuje se učinkovitijim u smanjenju recidivizma od pristupa usmjerenih samo na izolaciju i onemogućivanje činjenja kaznenih djela, odnosno na nadzor, praćenje i kontrolu

— bolje rezultate daju modeli istovremeno usmjereni na zaštitu zatvorenika i zaštitu zajednice, to jest oni usmjereni i na rizike i na kriminogene potrebe, koji podrazumijevaju aktivnu participaciju zatvorenika, u okviru kojih se s poslijepenalnom zaštitom započinje rano, uz minimiziranje negativnih učinaka zatvaranja i izradu integracijskog plana usmjerenog na kognitivni razvoj, razvoj vještina i povezivanje sa sadržajima u zajednici nakon otpusta

— na viši procijenjeni rizik potrebno je odgovoriti s više intervencija i usluga, uz primjenu svih triju komponenti načela responzivnosti

— učinkovitom socijalnom reintegracijom zatvorenika najbolje se štiti društvo u cjelini, pri čemu samo poslijepenalna zaštita usmjerena na dugoročne ciljeve integracije može dovesti i do dugoročnih koristi za društvo.

Za učinkovitu socijalnu reintegraciju zatvorenika potrebna je jasna posvećenost države, uz permanentno poboljšavanje postojećega zakonskog i regulatornog okvira za rehabilitacijske i reintegracijske programe da bi se prepoznale i premostile prepreke koje mogu biti ograničavajuće u primjeni empirijski potvrđenih spoznaja (United Nations Office on Drugs and Crime, 2012).

Analizirajući empirijski potvrđene spoznaje vezano uz uspješnu reintegraciju zatvorenika u zajednicu, Durnescu (2011) sumira važne preporuke, shodno već iznesenim spoznajama u ranijim poglavljima ovog rada. U svrhu odgovaranja na postavljeni prvi izazov, važnim ističe:

(1) priprema otpusta treba započeti što je prije moguće nakon pravomoćne sudske odluke

(2) proces treba biti osmišljen na način kojim se osigurava povezanost između aktivnosti u zatvoru i nakon otpusta

(3) potrebno je omogućiti postupnost u reintegraciji mogućnostima poput: kuća na pola puta, dnevnim boravcima i sličnim

(4) poruka koju zatvorenik treba dobiti od osoblja jest da je sam odgovoran za svoj život i da je promjena moguća

(5) motivacija zatvorenika i kvaliteta rada institucije odnosno organizacije koja provodi intervencije i daje usluge ključni su elementi za uspješnu reintegraciju

(6) zatvorski programi trebaju biti usmjereni na razvoj ljudskog kapitala (razvoj vještina rješavanja problema, strukovno obrazovanje, tretmani ovisnosti i tako dalje) s posebnim naglaskom na tranzicijske mehanizme

(7) programi izravno prije otpusta i programi nakon otpusta trebaju nastaviti rad na postignutome tijekom izvršavanja kazne zatvora i usredotočiti se na podržavanje motivacije i razvoj socijalnog kapitala (na primjer, obitelj, socijalna mreža, zapošljavanje itd.) 
(8) zajednice bi trebale biti svjesne rizika koji predstavlja socijalna isključenost otpuštenog zatvorenika

(9) država treba podržavati rehabilitacijski pristup, a ne pristupe koji dovode do socijalne isključenosti

(10) ravnoteža između prava na informacije i prava na privatnost treba biti uspostavljena na način kojim se promovira socijalna reintegracija, a ne nepotrebna i nepravedna stigma.

Posebnu pozornost bilo bi potrebno posvetiti roditeljskoj ulozi zatvorenika i potrebama njihove djece, uz uključivanje služba mjerodavnih za brigu o djeci, u čemu kvalitetan vodič svakako mogu biti postojeća Europska stajališta o dobroj praksi (Children of Prisoners Europe, 2015). U okviru zakonodavstva trebalo bi odvojeno definirati prava i pogodnosti zatvorenika na posjete općenito, od prava zatvorenika na posjete djece (Jovanović i Petrović, 2019). Obitelji (otpuštenog) zatvorenika potrebno je što prije ponuditi i pružiti im potrebnu pomoć i podršku da bi ostala integrirana ili bi se integrirala u postojeću socijalnu mrežu i da bi mogla pružiti podršku zatvoreniku tijekom kazne i nakon otpusta (Décarpes i Durnescu, 2014; Maloić, 2013).

Tražeći odgovore na drugi izazov, Mejovšek (1989, prema Žakman-Ban, 1992) kod povratnika konstatira nužnim analizirati zbog čega ranije mjere nisu dale rezultate i u tom smjeru individualno i opće unapređivati poslijepenalnu zaštitu. Nugent i Pitts (2009) smatraju da nije iznenađujuće što je dosadašnji napredak na području poslijepenalne zaštite još uvijek skroman, s obzirom na složenost i zahtjevnost procesa reintegracije zatvorenika. U smjeru postizanja veće učinkovitosti, Décarpes i Durnescu (2014) naglašavaju da bi istraživanja povezanih s reintegracijom svakako trebalo biti više, uz dodatno ulaganje napora u približavanje rezultata kreatorima politike i praktičarima. Naime, rezultati istraživanja nerijetko se ignoriraju ili se spoznaje dobivene istraživanjima pojednostavnjuju radi lakše primjene (Durnescu, 2011; Serin i sur., 2010).

U pokušajima prevladavanja trećeg izazova, sve su prisutnija mišljenja da bi svrhu poslijepenalne zaštite trebalo ponovno jače naglasiti u smislu socijalne reintegracije počinitelja, a ne samo u svrhu smanjenja recidivizma. Na taj bi se način jasnije potvrdila nužnost uključivanja različitih partnera u zajednici iz javnog i nevladina sektora, koji mogu pridonijeti reintegraciji zatvorenika - ne samo zbog njega samoga, već i zbog dobrobiti svih koji su na bilo koji način povezani, ili na koje može imati učinak njegovo zatvaranje i njegov povratak iz zatvora. Nadalje, ključnim se smatra paradigmu procesa prestanka i odvraćanja od činjenja kaznenih djela, iz sveučilišta i profesionalnog svijeta probacijske službe i zatvorskog sustava, vratiti u zajednice gdje se ovaj proces zapravo i događa (Maruna, 2017). U tom smjeru predstavnici zajednice trebali bi biti svjesniji posljedica socijalne isključenosti otpuštenih zatvorenika i aktivno uključeni u njihovu reintegraciju, to jest trebalo bi težiti uključivanju svih dionika iz zajednice u proces dugoročnog rješavanja problema (Basile, 2001; Maloić, 2013).

Lotar, Kamenov i Lebedina Manzoni (2010) navode da stigmatizacija počinitelja kaznenih djela često uključuje uvjerenje da su počinitelji jednostavno loše osobe koje se ne mogu promijeniti. Stoga je potrebno raditi na poticanju integracijskog umjesto izolacijskog pristupa i u tom smislu posebnu pozornost posvetiti educiranju šire društvene zajednice u sagledavanju svoje ključne uloge u vidu spremnosti za pomaganje zatvoreniku bez diskriminacije (Previšić i Leko, 1988; Srnić 
i Vulević, 2016). Nadalje, država bi svakako trebala imati što aktivniju ulogu poticanjem zapošljavanja otpuštenih zatvorenika, sustavno nudeći subvencije poslodavcima koji zapošljavaju bivše zatvorenike i programe samozapošljavanja (Jovanić, 2017a, prema Jovanić, Petrović i Savić, 2017). Intervencije usmjerene na socijalnu reintegraciju podrazumijevaju nastojanja različitih segmenata kazneno-pravnog sustava, u partnerstvu sa socijalnim agencijama, nevladinim sektorom, obrazovnim institucijama, zajednicom i obitelji zatvorenika, u svrhu učinkovite reintegracije i prevencije kriminalnog povrata (United Nations Office on Drugs and Crime, 2012).

\section{ZAKLJUČAK}

Kao što je uvodno navedeno, svrha je ovog rada pridonijeti većoj znanstvenoj utemeljenosti i učinkovitosti intervencija koje se u našoj zemlji poduzimaju na području poslijepenalne zaštite. Jedan je od ciljeva rada bio doprinijeti boljem razumijevanju na terminološkoj razini. U radu je provedena detaljna analiza s tom tematikom povezanih stranih i domaćih pojmova, s obzirom na prijepore oko naziva i značenja različitih pojmova koji se često koriste kao sinonimi. Slijedom svega navedenoga, a temeljem triju osnovnih kriterija: (1) nositelj i dionici, (2) sadržaj intervencija i (3) opseg i trajanje intervencije, predlaže se korištenje već postojećih pojmova u našoj zemlji na sljedeći način:

— poslijepenalni prihvat - odnosi se na izravnu pripremu zatvorenika za izlazak na slobodu, to jest na pripremu dokumenata, smještaja, odjeće, obuće, elementarnih novčanih sredstva za život. Naglasak je na pomoći u prvim danima i tjednima te na stvaranju elementarnih preduvjeta za život u zajednici bez počinjenja kaznenog djela odmah nakon otpusta. Nositelj je i inicijator zatvorski sustav koji prema potrebi angažira druge dionike, a aktivnosti su usmjerene na prvo vrijeme povratka zatvorenika u zajednicu.

- poslijepenalni tretman - odnosi se na nastavak svih općih i posebnih programa koji su se provodili u zatvoru odnosno u kaznionici - primjerice, nastavak liječenja ovisnosti, zapošljavanje i zadržavanje zaposlenja, nastavak obrazovanja. Obuhvaća sve programe usmjerene na podršku dugoročnoj socijalnoj integraciji. Inicijator je zatvorski sustav, dok su nositelji različite institucije i organizacije u zajednici. Naglasak je na tretmanskim, odnosno rehabilitacijskim programima.

— poslijepenalna pomoć - podrazumijevaju se usluge iz domene socijalne skrbi pri čemu pružatelji usluga mogu biti: sustav socijalne skrbi, lokalna zajednica i nevladin sektor. Može se odnositi na kratkotrajne oblike pomoći nakon izlaska na slobodu, ali i na trajnije oblike pomoći primjerice kod radno nesposobnih osoba, kronično bolesnih i nemoćnih osoba te osoba s invaliditetom.

— poslijepenalna zaštita - podrazumijevaju se sve aktivnosti koje se poduzimaju u smjeru zaštite zatvorenika, njegove obitelji i zajednice, tijekom zatvorske kazne i nakon izvršavanja kazne zatvora. U tom kontekstu autorica se u ovom radu odlučila koristiti pojmom poslijepenalna zaštita, već ranije argumentirajući svoj izbor, uz pojašnjenje sadržaja ovog pojma. 
Drugi je cilj rada bio pružiti pregled aktualnih inozemnih i domaćih spoznaja i rezultata empirijskih istraživanja u području poslijepenalne zaštite te ih staviti u kontekst aktualne hrvatske prakse u vidu preporuka. $U$ radu su u tu svrhu prikazani i različiti modeli poslijepenalne zaštite u svijetu. Da bi rad na socijalnoj reintegraciji zatvorenika, odnosno na području poslijepenalne zaštite u našoj zemlji bio učinkovitiji, temeljem provedenih analiza ključnim se na nacionalnoj razini smatra:

(1) sagledati postojeću domaću praksu u odnosu na preporučene pristupe, modele, standarde i prakse dokazane i obećavajuće učinkovitosti

(2) analizirati postojeće zakonske propise, donijeti posebne izmjene i nadopune, a prema procjeni potrebe donijeti i poseban Zakon o poslijepenalnoj zaštiti

(3) osmisliti Nacionalnu strategiju unapređivanja poslijepenalne zaštite s naglaskom na međuresornoj suradnji i komunikaciji sa zajednicom i medijima, uz izradu Akcijskog plana

(4) izraditi posebne protokole poslijepenalne zaštite za rad s povratnicima i visokorizičnim zatvorenicima

(5) osigurati potrebne ljudske i materijalne resurse za primjenu zakonskih odredaba i strateških dokumenata.

Financijska sredstva koja će biti potrebna u smislu većeg ulaganja u poslijepenalnu zaštitu mogu se činiti velikim problemom, naročito u vremenima nepovoljnih socioekonomskih uvjeta, međutim neulaganje i minimalno ili nedovoljno ulaganje u to područje dovodi do velikih troškova na drugim područjima, a ti bi troškovi na ovaj način mogli biti znatno smanjeni. Potreba za poslijepenalnom zaštitom jasna je sa stajališta mogućih negativnih posljedica zatvorske kazne, obilježja populacije, izazova povratka u zajednicu i mogućih učinaka neuspjele reintegracije. Učinkovita poslijepenalna zaštita uz rehabilitacijski pristup doprinosi zaštiti počinitelja, njegove obitelji, postojećih i potencijalnih žrtava, njihovih obitelji i društva u cjelini. Smanjenje recidivizma najučinkovitije se postiže prevencijom socijalnog isključivanja zatvorenika i njegovom socijalnom reintegracijom. Koristi ulaganja u poslijepenalnu zaštitu znatno premašuju troškove koji se u tu zaštitu trebaju uložiti, imajući u vidu troškove izvršavanja kazne zatvora, a posebno i s obzirom na dodatne koristi na područjima obrazovanja, zapošljavanja, zdravstva i socijalne skrbi. Prilikom osmišljavanja i planiranja ključno je rukovoditi se rezultatima istraživanja, to jest odlučiti se za modele, intervencije i usluge čija je učinkovitost dokazana i provoditi ih na učinkovit način. Kad god je to moguće, značaj poslijepenalne zaštite potrebno je argumentirati političkim strukturama, široj javnosti i lokalnim zajednicama.

S obzirom na jasno vidljiv nedostatak akademskog interesa za tu temu, ovim se radom između ostalog pokušalo potaknuti taj interes. Područje poslijepenalne zaštite iznimno je veliko i složeno područje koje stoga, zbog ograničena obima ovog rada, nije moglo biti detaljnije obrađeno u svim područjima i segmentima. Nužni su daljnji domaći znanstveni i stručni radovi kojima bi se opširnije i detaljnije analizirali i istražili pojedini segmenti i područja uz dodatne specifične preporuke, kao što su primjerice zakonodavstvo i domaća praksa, potrebe hrvatskih zatvorenika i otpuštenih zatvorenika (za strukovnim obrazovanjem, radom i zapošljavanjem, stambenim zbrinjavanjem i drugim važnim segmentima poslijepenalne zaštite), izazovi s kojima se susreću obitelji zatvorenika. Posebno 
se važnim čini istraživanje koje bi se provelo na uzorku povratnika s izvršavanja kazne zatvora, s obzirom da je postotak povratnika u tom dijelu kod nas značajan (Ministarstvo pravosuđa, 2020).

\section{LITERATURA}

Andrews, D. A., Bonta, J. \& Wormith, S. J. (2006). The recent past and near future of risk and/or need assessment. Crime \& Delinquency, 52(1), 7-27.

Bakić, D. (2001). Prikaz nekih modela institucionalnog tretmana počinitelja kaznenih djela. Ljetopis socijalnog rada, 8(1), 35-50.

Basile, V. D. (2002). A Model for Developing a Reentry Program. Federal Probation, 66(3), 55-58.

Bašić, J. (2001). Predgovor. U M. Mejovšek (ur.), Prema modelu intervencija u kaznenim zavodima (21 - 33). Zagreb: Edukacijsko - rehabilitacijski fakultet Sveučilišta u Zagrebu.

Bonta, J. \& Andrews, D. (2012). Viewing offender assessment and rehabilitation through the lens of the risk-need-responsivity model. In McNeill, F., Raynor, P., Trotter, C. (Eds.), Offender Supervision: New directions in theory, research and practice (19-38). Abingdon: Routledge.

Borovec; K. i Burazer, M. (2007). Zaštita žrtava kaznenih djela. Policija i sigurnost, 16(1-2), 67-87.

Brinc, F. (1976). Pomoč odpuščenim obsojencem. Revija za kriminalistiko in kriminologijo, 27(3), 172-183.

Brinc, F. (1982). Nastanitev odpuščenih obsojencev. Socialno delo, 21(1), 324-341.

Brinc, F. (1989). Teoretična in praktična vprašanja postpenalne pomoči. Socialno delo, 28(4), 365- 387.

Brkić, L. (2013). Djeca čiji su roditelji na izdržavanju kazne zatvora. Socijalna politika i socijalni rad, 1(1), 8-37.

Brozić Perić, T., Zelić, R. i Tepšić, M. (2017). Postupanje centra za socijalnu skrb u odnosu na korisnike u zatvoru i povratnike iz zatvora. U K., Radat, Majdak, M., Jovović l., (ur.) Zbornik radova 1. konferencije prevencije i smanjenja socijalne isključenosti: Integrirani osuđenici - socijalno pravednije društvo (str.43-51). Zagreb: Društvo za socijalnu podršku.

Buđanovac, A. i Mikšaj-Todorović, Lj. (2002). Stavovi prema osuđenicima i njihovoj rehabilitaciji na slovenskom i hrvatskom uzorku ispitanika. Kriminologija i socijalna integracija, 10(2), 153-160.

Burnett, R. \& Maruna, S. (2006). The kindness of prisoners: Strengths-based resettlement in theory and in action. Criminologogy \& Criminal Justice, 6(1), 83-106.

Butorac, K., Gracin, D. i Stanić, N. (2017). The Challenges in Reducing Criminal Recidivism. Preuzeto s: https://pdfs.semanticscholar.org/ebe9/067c6c5555b0c926a0d65203dfbf89f216ad. $p d f ? \_g a=2.112651970 .778258887 .1576243496-643626993.1576243496$ (1.12.2019).

Capul, M. (1973). Odgojne grupe. Savez društava defektologa Jugoslavije. Beograd.

Children of Prisoners Europe (2015). Djeca čiji su roditelji u zatvoru - Europska stajališta o dobroj praksi. Pariz: Children of Prisoners Europe i Zagreb: Pravobranitelj za djecu RH.

Connor, D. P., Copes, H. \& Tewksbury, R. (2011). Incarcerated sex offenders' perceptions of prison sex offender treatment programs. Justice Policy Journal, 8(2), 1-22.

Cotter, L. (2015). Are the Needs of Adult Offenders with Mental Health Difficulties being met in Prisons and on Probation? Irish Probation Journal, 12, 57-78. 
Council of Europe (2010). Recommendation CM/Rec (2010)1 of the Committee of Ministers to member states on the Council of Europe Probation Rules. Preuzeto s https://www. pmscr.cz/download/mezdoken_European_Probation_Rules.pdf (12.4.2019).

Council of Europe (2006). European Prison Rules. Preuzeto s https://search.coe.int/ cm/Pages/result_details.aspx?Object $I D=09000016805 d 8 d 25$ (11.4.2020).

Council of Europe (2010). Recommendation CM/Rec (2010) 1 of the Committee of Ministers to member states on the Council of Europe Probation Rules. Preuzeto s https://www.pmscr.cz/ download/mezdoken_European_Probation_Rules.pdf (12.4.2019).

Cowe, F. (2012). Towards a desistance focused practice with Sex offenders in Approved Premises/ Hostels. EuroVista, 2(1), 35-38.

Crawley, E. (2004). Release and Resettlement: the perspectives of older prisoners. Criminal Justice Matters, 56, 32-33.

Cuéllar, A. F., Tortosa, M. C., Dreckmann, K., Markov, D. \& Doichinova, M. (2015). Vulnerable Groups of Prisoners: A Handbook. Sofia: Center for the Study of Democracy.

Cullen, F. T. \& Gendreau, P. (2001). From Nothing Works to What Works: Changing Professional Ideology in the 21st Century. Prison Journal, 81(3), 313-338.

Damjanović, I., Šarić, J. i Mikšaj-Todorović, Lj. (2000). Neki problemi tretmana osuđenih osoba u Republici Hrvatskoj. Kriminologija i socijalna integracija, 8(1-2), 103-116.

Décarpes, P. \& Durnescu, I. (2014). Where are we in resettlement research? EuroVista, 3(2), 47-67.

Denney, A. S., Tewksbury, R. \& Jones, R. S. (2014). Beyond Basic Needs: Social Support and Structure for Successful Offender Reentry. Journal of Qualitative Criminal Justice and Criminology, 2(1), 39-67.

Dhami, M. K., Mandel, D. R., Loewenstein, G. \& Ayton, P. (2006). Prisoners' Positive Illusions of Their Post-Release Success. Law and Human Behavior, 30(6), 631-647.

DiZerega, M. (2010). Engaging Offenders' Families in Reentry. Vera Institute of Justice. Preuzeto s https://www.cdcr.ca.gov/Reports/docs/External-Reports/Engaging-Offenders-Families-in-Reen try.pdf (21.9.2018.).

Doležal, D. i Jandrić, A. (2002). Institucionalni penološki programi s ovisnicima o ilegalnim drogama. Kriminologija i socijalna integracija, 10(2), 105-117.

Doležal, D. i Mikšaj-Todorović, Lj. (2008). Povezanost kriminogenih rizika i potreba s kriminalnim stilovima razmišljanja. Kriminologija i socijalna integracija, 16(1), 25-32.

Durnescu, I. (2011). Resettlement research and practices. An international perspective. A report commissioned by the European Organisation for Probation. Utrecht: Confederation of European Probation.

Duwe, G. (2017). The use and impact of correctional programming for inmates on pre- and post-release outcomes (NCJ 250476). Washington, DC: U.S. Department of Justice, National Institute of Justice.

Đoković, L. (2019). Mediji, kriminalitet i mladi. Revija za kriminologiju i krivično pravo, 57(2), 113-130.

Edukacijsko-rehabilitacijski fakultet (2019). Diplomski studij Socijalna pedagogija. Sveučilište u Zagrebu. Preuzeto s http://www.erf.unizg.hr/hr/studiji/diplomski-socijalna-pedagogija\#iv-seme star (10.4.2019.). 
Fox, A., Khan, L., Briggs, D., Rees-Jones, N., Thompson, Z. \& Owens, J. (2005). Throughcare and aftercare: approaches and promising practice in service delivery for clients released from prison or leaving residential rehabilitation. Home Office Online Report 01/05. Preuzeto s https://www.drugsandalcohol.ie/5960/1/Home_office_throughcare_and_aftercare.pdf (26.9.2018.).

Franjić-Nađ, B., Badurina-Sertić, Đ., Šimić, Z. i Pavešić-Herkov, Đ. (2015). Kontakti zatvorenika s obitelji - rezultati istraživanja. Ministarstvo pravosuđa. Preuzeto s https://pravosudje. gov.hr/UserDocs/mages/dokumenti/Prezentacije/Zatvorski\%20sustav/Kontakt\%20zatvorenika\%20s\%20obitelji_sazetak.pdf (4.5.2020).

Gabelica Šupljika, M. (2009). Odrastanje djeteta čiji je roditelj u zatvoru-psihologijski pogled i europska iskustva. U M. Gabelica Šupljika (ur.), Prava djece čiji su roditelji u zatvoru (11-31). Zagreb: Pravobranitelj za djecu.

Griffiths, C.T., Dandurand, Y. \& Murdoch, D. (2007). The Social Reintegration of Offenders and Crime Prevention. Public Safety Canada. Research Report: 2007-2. Preuzeto s https://www. publicsafety.gc.ca/cnt/rsrcs/pblctns/scl-rntgrtn/scl-rntgrtn-eng.pdf (9.10.2019).

Griffiths, C.T. \& Murdoch, D.J. (2009). Strategies and Best Practices against Overcrowding in Correctional Institutions. The International Centre for Criminal Low Reform and Criminal Justice Policy. Preuzeto s http://www.antoniocasella.eu/nume/Griffiths_2009.pdf (15.6.2018.).

Hermans, J. (2009). The Wraparound Process in Probation Service. EuroVista, 1(3), 129-136.

Hurry, J., Brazier, L., Parker, M. \& Wilson, A. (2006). Rapid Evidence Assessment of Interventions that Promote Employment for Offenders. Research report RR747, Institute of Education, Department for Education and Skills. Preuzeto s https://www.researchgate.net/publication/266047946_Rapid_Evidence_Assessment_of_Interventions_that_Promote_Employment_for_Offenders (18.9.2018).

Hrvatski zavod za zapošljavanje (2020). Mjesečni statistički bilten za ožujak 2020. Preuzeto s https:// www.hzz.hr/content/stats/0320/HZZ_stat_bilten_03_2020.pdf (28.4.2020).

Ilijaš, A. i Podobnik, M. (2018). Nestabilnost zakona o socijalnoj skrbi - kako utječe na rad socijalnih radnika u centrima za socijalnu skrb?. Ljetopis socijalnog rada, 25(3), 427-450. doi: https://doi.org/10.3935/ljsr.v25i3.242

Jandrić, A., Puljić, V., i Cetinić D (2005). Institucionalni i poslijepenalni tretman osuđenih ovisnika.

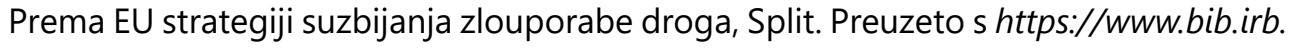
$h r / 227298$ (10.4.2019).

James, N. (2015). Offender Reentry: Correctional Statistics, Reintegration into the Community, and Recidivism. Congressional Research Service. Preuzeto s https://fas.org /sgp/crs/misc/ RL342 87.pdf. (19.1.2017.).

James, N. (2018). Risk and Needs Assessment in the Federal Prison System. Congressional Research Service. Preuzeto s https://fas.org/sgp/crs/misc/R44087.pdf (28.11.2019).

Jelavić, M. (2009). Obiteljskopravna i socijalna zaštita djeteta čiji je roditelj u zatvoru. U M. Gabelica Šupljika (ur.), Prava djece čiji su roditelji u zatvoru (47-56). Zagreb: Pravobranitelj za djecu.

Joldersma, C. (2016). Developments in prison and probation practice. EuroVista, 4(2). Preuzeto s https://www.cep-probation.org/wp-content/uploads/2019/01/NOL-4.2-Developments-in-prison-and-probation-practice-.pdf (29.10.2019). 
Jovanić, G., Petrović, V. i Savić, A. (2017). Karakteristike osuđenih na kratke i duge kazne. Zbornik Instituta za kriminološka i sociološka istraživanja, XXXVI(3), 39-58.

Jug, L. (2013). Socijalna skrb u Republici Hrvatskoj - aktualno stanje i izazovi. Socijalna politika $i$ socijalni rad, 1(1), 130-131.

Jukić, R. i Sabljo, M. (2017). Penološka andragogija - zatvorski tretman i mogućnosti resocijalizacije zatvorenika. Andragoški glasnik, 21(1-2 (36), 27-36.

Kanduč, Z. (1996). Zamisao o rehabilitaciji: pogled s kriminološkog stajališta. Kriminologija i socijalna integracija, 4(2), 142-148.

Knežević, M. (2008). Penologija u socijalnom radu (i socijalni rad u penologiji). Zagreb: Pravni fakultet, Studijski centar socijalnog rada, Zavod za socijalni rad.

Koller-Trbović, N., i Mirosavljević, A. (2005). Posttretman-pomoć nakon institucije ili što nakon tretmana. Kriminologija i socijalna integracija, 13(2), 99-109.

Kobal, B. i Žakelj, T. (2007). Osebe v postpenalni obravnavi na trgu dela. Socijalno delo, 46(3), 157-165.

Kovčo, I. (1997). Penološki institucionalni tretman počinitelja ubojstva. Kriminologija i socijalna integracija, 5(1-2), 53-66.

Kovčo Vukadin (2011). Analiza dinamike i strukture kriminaliteta u Republici Hrvatskoj u razdoblju između dviju velikih reforma kaznenog zakonodavstva (1997.-2011.). Hrvatski ljetopis za kazneno pravo i praksu, 18(2), 359-416.

Latessa, E. J. \& Lowenkamp, C. T. (2006). What Works in Reducing Recidivism? University of St. Thomas Law Journal, 3(3), 521-535.

Laušić, F. $(2020,1)$. Stopa nezaposlenosti u Hrvatskoj pala na povijesno nisku razinu. Jutarnji list. Preuzeto s https://novac.jutarnji.hr/aktualno/stopa-nezaposlenosti-u-hrvatskoj-pala-na-povijes no-nisku-razinu/9842566/ (9.4.2020)

La Vigne, N. G., Solomon, A., Beckman, K. \& Dedel, K. (2006). Prisoner Reentry and Community Policing: Strategies for Enhancing Public Safety. Washington, D.C.: Urban Institute. Preuzeto s https://www.urban.org/sites/default/files/publication/50716/411061-Prisoner-Reentry-and-Community-Policing.PDF (24.9.2018.).

Lewis, G. (2013). Older people in prison. EuroVista, 2(3), 161-167.

Listwan, S. J., Cullen, F. T. \& Latessa, E. J. (2006). How to Prevent Prisoner Re-entry Programs from Failing: Insights from Evidence-Based Corrections. Federal Probation, 70(3), 19-25.

Logarušić, M. i Raguž Krištić, I. (2019). Odrednice nezaposlenosti u Europskoj uniji. Ekonomski pregled, 70(4), 575-602.

Lončar, P. (2016). Priprema za izlazak na slobodu i poslijepenalni prihvat zatvorenika. Diplomski rad. Sveučilište u Zagrebu, Edukacijsko- rehabilitacijski fakultet, Zagreb. Preuzeto s https://repozitorij.erf.unizg.hr/islandora/object/erf:134/preview (9.4.2019).

Lotar, M., Kamenov, Ž. i Lebedina Manzoni, M. (2010). Spolne razlike u stigmatizaciji osuđenih počinitelja kaznenih djela. Kriminologija i socijalna integracija, 18(2), 1-104.

Lotar Rihtarić, M., Vrselja, I. i Badurina-Sertić, Đ. (2017). Individualni čimbenici zatvorenika: što doprinosi penalnom recidivizmu? Ljetopis socijalnog rada, 24(3), 539-563.

MacDonald, M., Williams, J. \& Kane, D. (2013). Throughcare for prisoners with problematic drug use: a European perspective. EuroVista, 2(3), 144-153. 
Mahmutović, Dž. i Hasanbegović, H. (2007). Organizacija postpenalne pomoći u Federaciji BIH i očekivanja osuđenica nakon izdržane kazne. Defektologija, 13(2), 197-202.

Maguire, M. \& Raynor, P. (2006). How the resettlement of prisoners promotes desistance from crime: Or does it? Criminology and Criminal Justice, 6(1), 19-38.

Maguire, M., Maguire, M., Kemshall, H., Noaks, L., Wincup, E. \& Sharpe, K. (2001). Risk Management of Sexual and Violent Offenders: The work of Public Protection Panels. Police Research Series -Paper 139. Preuzeto s http://library.college.police.uk/docs/hopolicers/prs139. pdf

Maguire, M. (2011). The resettlement of ex-prisoners. U L. Gelgsthorpe, R. Morgan (ur.), Handbook of Probation (str. 398-424). Abingdon: Routledge.

Majdak, M. (2018). Zaboravljena djeca - poteškoće vezane uz zaštitu prava djece čiji su roditelji u zatvoru. Revija za socijalnu politiku, 25(1), 67-83.

Maloić, S. (2013). Suvremeni pristupi kažnjavanju kao determinante kvalitete života u obitelji, susjedstvu i zajednici-nove perspektive suzbijanja kriminala. Kriminologija I socijalna integracija, 21(2), 1-164.

Maloić, S. (2016). Dominantna načela i modeli tretmanskog rada s punoljetnim počiniteljima kaznenih djela u zajednici. Kriminologija i socijalna integracija, 24(2), 115-139. doi: https:// doi.org/10.31299/ksi.24.2.6

Maloić, S., Mažar, A. i Jandrić Nišević, A. (2013). Zlouporaba droga - pristupi, paradigme i načini rada u okviru probacije. Ljetopis socijalnog rada, 20(3), 481-508.

Maloić, S. i Rajić, S. (2012). Potreba i značaj razvoja suradnje probacijskog sustava i sustava socijalne skrbi u RH. Ljetopis socijalnog rada, 19(1), 29-52.

Maloić, S., Ricijaš, N. i Rajić, S. (2012). Povijesni razvoj i modeli ranijeg otpusta zatvorenika: značaj za aktualnu hrvatsku kaznenopravnu praksu. Kriminologija i socijalna integracija, 20(2), 29-46.

Maloić, S., Rajić, S. i Mažar, A. (2015). Značaj suradnje probacijskog i zatvorskog sustava u prevenciji kriminalnog povrata. Kriminologija i socijalna integracija, 23(1), 129-156.

Markson, L., Lösel, F., Souza, K. \& Lanskey, C. (2015). Male prisoner's family relationships and resilience in resettlement. Criminology and Criminal Justice, 15(4), 423-441.

Maruna, S. (2006). Who Owns Resettlement? Towards Restorative Re-Integration. British Journal of Community Justice, 4(2), 23-33.

Maruna, S. (2017). Desistance as a Social Movement. Irish Probation Journal, 14, 5-20.

Marussig, Š. (2017). Negotovost pred ospustom in postpenalna obravnava obsojenk. Diplomsko delo. Univerza u Ljubljani, Pedagoška fakulteta.

Matak, Š. (2010). Prava djece čiji su roditelji na izdržavanju zatvorske kazne. Pravnik, 44(88), 155-164.

McAlinden, A. (2016). The Reintegration of Sexual Offenders. Irish Probation Journal, 13, 5-21.

McNally, G. \& Brennan, A. (2015). Community Return: A Unique Opportunity. Irish Probation Journal, 12, 141-159.

McNeill, F. (2006). A desistance paradigm for offender management. Criminology and Criminal Justice, 6(1), 39-62.

McNeill, F. (2012). Four forms of 'offender' rehabilitation: towards an interdisciplinary perspective. Legal and Criminological Psychology, 17(1), 18-36. 
Mears, D. P., Cochran, J. C., Siennick, S. E. \& Bales, W. D. (2012). Prison Visitation and Recidivism. Justice Quarterly, 39(6), 888-918.

Mejovšek, M. (1995). Povezanost između nekih osobnih obilježja osuđenih za kaznena djela razbojstva i razbojničke krađe i prognoze uspjeha resocijalizacije. Kriminologija i socijalna integracija, 3(1), 21-35.

Mejovšek, M. (2001). Temeljni problem penološkog tretmana. U M. Mejovšek (ur.), Prema modelu intervencija u kaznenim zavodima (21 - 33). Zagreb: Edukacijsko - rehabilitacijski fakultet Sveučilišta u Zagrebu.

Mejovšek, M. (2002). Uvod u penološku psihologiju. Jastrebarsko: Naklada Slap; Zagreb: Edukacijsko-rehabilitacijski fakultet.

Mejovšek, M., Lebedina-Manzoni, M., Lotar, M., i Šarić, J. (2007). Percepcija psihosocijalne klime i osobine ličnosti zatvorenika. Kriminologija i socijalna integracija, 15(1), 1-12.

Mikšaj, LJ. (1982). Povezanost kriminalne aktivnosti i oblika devijantnog ponašanja u postpenalnom periodu. Defektologija, 18(1-2), 217-222.

Mikšaj-Todorović, Lj., i Buđanovac, A. (1999). Socijalno pedagoški programi: uvjet za komunikaciju izmedu struke i javnosti. Kriminologija i socijalna integracija, 7(1), 57-65.

Mikšaj-Todorović, LJ., i Buđanovac, A. (2001). Obilježja primarne obitelji I fenomen povratništva. U M. Mejovšek (ur.), Prema modelu intervencija u kaznenim zavodima (93 - 113). Zagreb: Edukacijsko - rehabilitacijski fakultet Sveučilišta u Zagrebu.

Mikšaj-Todorović, Lj. i Buđanovac, A. (2002). Javno mnijenje o prijestupnicima i rehabilitaciji u Hrvatskoj: utjecaj spola, dobi, obrazovanja i razine urbanizacije. Kriminologija i socijalna integracija, 8(1-2), 27-34.

Mikšaj-Todorović, Lj., Buđanovac, A., i Brgles, Ž. (1998). Rehabilitacijski programi u institucijama u Hrvatskoj penološkoj teoriji i praksi. Hrvatska revija za rehabilitacijska istraživanja, 34(1), 83-92.

Mikšaj-Todorović, Lj. i Leko, M. (1995). Strukturiranje vremena osuđenika u relaciji s općom procjenom njihova ponašanja u kaznenom zavodu. Kriminologija i socijalna integracija, $3(2), 151-164$.

Ministarstvo pravosuđa (2020). Izvješće o stanju i radu kaznionica, zatvora i odgojnih zavoda za 2018. godinu. Preuzeto s https://www.sabor.hr/sites/default/files/uploads/sabor/2020-01-03/162702/IZVJESCE_KAZNIONICE_2018.pdf (4.5.2020)

Ministry of Justice (2018). Multi-Agency Public Protection Arrangements - Annual Report 2017/18. London. Preuzeto s https://assets.publishing.service.gov.uk/government/uploads/ system/uploads/attachment_data/file/751006/mappa-annual-report-2017-18.pdf (9.11.2019).

Nugent, B. \& Pitts, S. (2009). Resettling Adult Offenders - a perfect opportunity for European Collaboration? EuroVista, 1(1), 38-43.

O'Neill, J. (2017). Women's Transitions from Custody in Northern Ireland - Time After Time? Irish Probation Journal, 14, 112-132.

Parliamentary Assembly (2006). Recommendation 1741 - Social reintegration of prisoners. Preuzeto s http://www.assembly.coe.int/nw/xml/XRef/Xref-XML2HTML-en.asp?fileid=17423\&la $n g=e n(14.4 .2020)$. 
Penić, Z., Malek, M. i Vlahović, K. (2017). Socijalna isključenost i postpenalni prihvat zatvorenika - izazovi moderne prakse. U K. Radat, M., Majdak, I., Jovović, (ur.) Zbornik radova 1. konferencije prevencije i smanjenja socijalne isključenosti: Integrirani osuđenici-socijalno pravednije društvo (str. 16-24). Zagreb: Društvo za socijalnu podršku.

Petersilia, J. (2000). When Prisoners Return to the Community: Political, Economic, and Social Consequences. Sentencing and Corrections Issues for the $21^{\text {st }}$ Century; Papers from the Executive Sessions and Sentencing and Corrections, 9. Washington, DC: National Institute of Justice.

Petersilia, J. (2001). When Prisoners Return to the. Community: Political, Economic, and Social Consequences. Federal Probation, 65(1), 3-8.

Petersilia, J. (2004). What Works in Prisoner Reentry? Reviewing and Questioning the Evidence. Federal Probation, 68(2), 4-8.

Petrović, V i Jovanić, G. (2019). Marginalizacija dece kao posledica inkarceracije roditelja. U J. Petrović i G. Jovanić (ur.), Zbornik radova Četvrte međunarodne naučne konferencije "Društvene devijacije, Položaj marginalizovanih grupa u društvu", (str. 201-212). 31. svibanj- 1. lipanj 2019. god., Banja Luka: Centar modernih znanja. doi: 10.7251/ZCMZ0119201P.

Petrović, V. i Jovanić, G. (2019). Obrazovanje osuđenih kao protektivni faktor u redukciji recidivizma. Andragoške studije, 1, 47-65.

Previšić. V. i Leko, M. (1988). Suradnja različitih faktora u postinstitucionalnoj zaštiti. Penološke teme, 3(3-4), 259-263.

Probation Board for Northern Ireland (2017). Probation Board for Northern Ireland (2017). Significant risk of serious harm to other procedures. Preuzeto s https://www.pbni. org.uk/wp-content/uploads/2015/02/Significant-Risk-of-Serious-Harm-Procedures-May-2017-26.07.17.pdf (12.12.2019)

Profaca, B. i Buljan Flander, G. (2009). Podrška djetetu čiji je roditelj u zatvoru. U M. Gabelica Šupljika (ur.), Prava djece čiji su roditelji u zatvoru (32-46). Zagreb: Pravobranitelj za djecu.

Raynor, P. \& Robinson, G. (2009). Why help offenders? Arguments for Rehabilitation as a Penal Strategy. European Journal of Probation, 1(1), 3-20.

Rentzmann, W. (2008). Prison policy, prison regime and prisoners' rights in Denmark. In Prison policy and prisoners' rights, Proceedings of the Colloquium of the IPPF, Stavern, Norway, 25-28 June 2008. Nijmegen: Wolf Legal Publishers.

Sarno, C., Hearnden, I., Hedderman,C., Hough, M., Nee, C. \& Herrington,V. (2000). Working Their way out of offending: an evaluation of two probation employment schemes. Home Office Research Study 218. Preuzeto s http://library.college.police.uk/docs/hors/hors218. pdf (19. rujan 2018.).

Shapland, J. \& Hall, M. (2007). What do we know about the effects of crime on victims? International Review of Victimology, 14, 175-217.

Seiter, R. P. \& Kadela, K. R. (2003). Prisoner Reentry: What Works, What Does Not, and What Is Promisnig. Crime \& Deliquency, 49(3), 360-388.

Serin, R. C., Lloyd, C. D. \& Hanby, L. J. (2010). Enhancing Offender Re-Entry: An integrated model for enhancing offender re-entry. European Journal of Probation, 2(2), 53-75.

Srnić, J. i Vulević, D. (2016). Moderno društvo i postpenalna praksa. Beograd: Neostart. Preuzeto s http://neostart.org/wp-content/themes/NEOSTART/download/Moderno_dru\%C5\% A1tvo_i_postpenalna_praksa.pdf (27.4.2019). 
Stevanović, I., Petrović, B., Međedović, J. i Vujičić, N. (2018). Ekspertsko istraživanje i analiza povrata u Republici Srbiji. Beograd: Institut za kriminološka i sociološka istraživanja.

Subramanian, R. \& Shames, A. (2013). Sentencing and Prison Practices in Germany and the Netherlands: Implications for the United States. New York: Vera Institute of Justice.

Sučić, I., Knežević, M. i Matijaš M. (2016). Majke u zatvoru - između propisanih i ostvarenih prava. Zagreb: Udruga Roda. Preuzeto s https://bib.irb.hr/datoteka/855633.MAME.pdf (6. travnja 2020.)

Špadijer-Džinić, J. (1973). Zatvoreničko društvo. Beograd: Institut za kriminološka i sociološka istraživanja.

Šućur, Z. (1995). Socijalnoekonomski i obiteljski status počinitelja kaznenih djela razbojstva i razbojničke krađe u relaciji s indikatorima učinkovitosti tretmana. Kriminologija i socijalna integracija, 3(2), 179-195.

Šućur, Z. (2001). Obilježja primarne obitelji i fenomen povratništva. U M. Mejovšek (ur.), Prema modelu intervencija u kaznenim zavodima (163 - 181). Zagreb: Edukacijsko - rehabilitacijski fakultet Sveučilišta u Zagrebu.

Tabar, O.F., Miravalle, M., Ronco, D. \& Torrente, G. (2016). Reducing the prison population in Europe: does community justice work? Roma: Antigone Edizioni. Preuzeto s http://www.ub.edu/ ospdh/sites/default/files/documents/epo_ws_1_final_report_reducing_the_prison_population_in_europe._does_community_justice_work.pdf (28.7.2018.).

Taxman, F. S. (2004). The Offender and Reentry: Supporting Active Participation and Reintegration. Federal Probation, 6(2), 31-35.

Travis, J. (2000). But They All Come Back: Rethinking Prisoner Reentry. Papers from the Executive Sessions on Sentencing and Corrections. No. 7. Research in Brief. Preuzeto s https:// www.ncjrs.gov/pdffiles 1/nij/181413.pdf (18.9.2018.

Travis, J., Solomon, A. L. \& Waul, M. (2001). From prison to Home: The Dimensions and Consequences of Prisoner Reentry. Washington, DC: Urban Institute.

United Nations (2016). United Nations Standard Minimum Rules for the Treatment of Prisoners (the Nelson Mandela Rules). Preuzeto s https://cdn.penalreform.org/wp-content/uploads/1957/06/ENG.pdf (16.4.2020).

United Nations Office on Drugs and Crime (2012). Introductory Handbook on the Prevention of Recidivism and the Social Reintegration of Offenders. New York: United Nations.

Ured za suzbijanje zlouporabe droga (2015). Izvješće o evaluaciji Projekta resocijalizacije ovisnika o drogama. Preuzeto s https://drogeiovisnosti.gov.hr/UserDocs/mages/dokumenti/Izvje\%C5\%A1\%C4\%87a/Izvje\%C5\%A1\%C4\%87e\%20o\%20evaluaciji/lzvje\%C5\%A1\%C4\%87e\%20o\%20evaluaciji\%20Projekta\%20resocijalizacije\%20ovisnika\%20(2015.).pdf (26.4.2020).

Uzelac, S., Žakman-Ban, V. i Farkaš, R. (2008). Rad zatvorenika u fazi adaptacije na zatvorske uvjete u hrvatskoj kaznionici. Kriminologija i socijalna integracija, 16(1), 79-108.

Vidmar, B. (2016). Postpenana pomoči in njen vpliv na resocijalizacijo in povratništvo. Diplomsko delo. Univerza v Mariboru, Pravna fakulteta, Bled.

Zakon o izvršavanju kazne zatvora. Narodne novine, 128/99, 55/00, 59/00, 129/00, 59/01, 67/01, $11 / 02,190 / 03,76 / 07,27 / 08,83 / 09,18 / 11,48 / 11,125 / 11,56 / 13,150 / 13,98 / 19$

Zakon o izvršenju krivičnih sankcija. Službeni glasnik RS, 55/2014, 35/2019. 
Zakon o izvršenju sankcija izrečenih za kaznena djela, privredne prijestupe i prekršaje. Narodne novine, 21/74, 39/74, 55/88, 19/90, 26/93, 66/93, 29/94, 111/97, 128/99, 73/00, 27/01, 55/00, 59/00, 129/00, 109/03, 153/09.

Zakon o probaciji. Narodne novine, 153/09.

Zakon o probaciji. Narodne novine, 143/12.

Zakon o probaciji. Narodne novine, 99/18.

Žakman-Ban, V. (1992). Povratništvo - uvijek aktualan krivičnopravni, kriminalistički i penološki problem. Kriminologija i socijalna integracija, 28(1-2), 93-110.

Ward, T., Yates, P. M. \& Willis, G. M. (2012). The Good Lives Model and the Risk Need Responsivity Model: A Critical Response to Andrews, Bonta i Wormith (2011). Criminal Justice and Behavior, 39(1), 94-110.

Welsh, B. C. (2004). Monetary Costs and Benefits of Correctional Treatment. Programs: Implications for Offender Reentry. Federal Probation, 68(2), 9-13.

Wisher, C. A. \& Travis, J. (2003): Transitions from prison to community: Understanding individual pathways. Annual Review of Sociology, 29, 89-113.

Wodier, N. (2013). Employment, reintegration and reducing re-offending - a short look into a offender resettlement within Europe. EuroVista, 2(3), 134-143.

Wormith, J. S., Althouse, R., Simpson, M., Reitzel, L. R., Fagan, T. J. \& Morgan, R. D. (2007). The Rehabilitation and Reintegration of Offenders: The Current Landscape and Some Future Directions for Correctional Psychology. Criminal Justice and Behavior, 34(7), 879-892. 


\title{
CONCEPT AND SIGNIFICANCE OF RESETTLEMENT - WHOM TO PROTECT, WHY, AND HOW?
}

\begin{abstract}
Resettlement is a very complex and demanding area and has been neglected from a political, social, financial, and professional point of view. This is definitively the case in the Republic of Croatia, but it also applies to other countries.

The topic, in terms of adult offenders sentenced to imprisonment, is underrepresented in the contemporary professional and scientific literature in Croatia. According to the information available to the author, there is no recent research about resettlement in our country.

This paper seeks to highlight the importance of prison aftercare protection and successful reintegration of released prisoners in terms of protecting the prisoners, their families, known and potential victims and society in general. The paper also aims to provide support to state and public institutions and the NGO sector in creating thoughtful and scientifically based measures of prison aftercare protection.

The purpose of the paper is to provide knowledge about evidence-based practice and effectiveness of interventions undertaken in Republic of Croatia in the field of resettlement. The goals of the paper are: (1) to contribute to better understanding of "resettlement terminology" which is important for researchers and practitioners working in that area, (2) to examine the results of contemporary empirical research in the context of improving the current Croatian practice and (3) to raise academic interest for the prison aftercare problems.

The concluding remarks include recommendations for the use of resettlement-related terminology and the ideas on how to improve resettlement in the Republic of Croatia. Also, some new topics and areas were addressed that call for additional analysis through papers and scientific research in our country.
\end{abstract}

Key words: resettlement, reentry, prison, prisoner, social reintegration 